\title{
Persistence of labile organic matter and microbial biomass in Antarctic shelf sediments: evidence of a sediment 'food bank'
}

\author{
Sarah L. Mincks ${ }^{1, *}$, Craig R. Smith ${ }^{1}$, David J. DeMaster ${ }^{2}$ \\ ${ }^{1}$ University of Hawaii, Department of Oceanography, 1000 Pope Road, Honolulu, Hawaii 96822-2225, USA \\ ${ }^{2}$ North Carolina State University, Department of Marine, Earth and Atmospheric Sciences, Box 8208, Raleigh, \\ North Carolina 27695-8208, USA
}

\begin{abstract}
The West Antarctic Peninsula (WAP) shelf experiences a highly seasonal flux of particulate organic carbon following the retreat of winter sea ice, which results in deposition of labile food material for benthic detritivores. We conducted a seasonal time-series study (November 1999 through March 2001) on the WAP shelf to determine the timing and magnitude of bloom deposition on the sea floor, and the effects of seasonal deposition on microbial biomass, and persistence of labile organic material in sediments. Despite substantial seasonal changes in particle flux, the concentrations and inventories of chlorophyll a (chl a) and enzymatically hydrolyzable amino acids (EHAA) in near-surface sediments showed only modest seasonal variation. Interannual differences in particle flux were also large, but evidence of an elevated flux was not observed below the top $3 \mathrm{~cm}$ of sediment. Chl a and EHAA penetrated deeply $(>5 \mathrm{~cm}$ ) into the sediments, and had long half-lives (months to years) even in high-flux summer months. These results provide evidence of a long-term sediment 'food bank' for detritivores. Microbial biomass was relatively high in the top $2 \mathrm{~cm}$ of the sediments $(\sim 1.5$ to $12.4 \mu \mathrm{g}$ ATP $\mathrm{g}^{-1}$ sediment), and showed only limited response to phytodetrital deposition. Despite high sediment inventories of labile organic matter and microbial biomass, rates of organic matter mineralization were in balance with sinking particle flux. We postulate that a requirement for high substrate concentrations for microbial mineralization of organic matter at low Antarctic temperatures may promote the existence of a 'food bank' of labile material in WAP shelf sediments. Further, effects of continued climatic warming on these sediments could enhance microbial remineralization of organic matter, decreasing background levels of labile material in sediments, and altering organic matter storage and food availability for detritivores on the WAP shelf.
\end{abstract}

KEY WORDS: Antarctic sediments $\cdot$ Microbial biomass $\cdot$ Chlorophyll a $\cdot$ Enzymatically hydrolyzable amino acids $\cdot$ Temperature-substrate limitation $\cdot$ Phytodetritus

\section{INTRODUCTION}

Many benthic ecosystem processes are strongly coupled to productivity patterns in the water column, both in shallow-water and deep-sea communities (e.g. Hargrave 1973, Deuser \& Ross 1980, Graf et al. 1982, 1983, Meyer-Reil 1983, Tyler 1988, Graf 1989, Billet et al. 2001). Recently, benthic-pelagic coupling has been studied in high-latitude oceans, where there are dramatic seasonal shifts in levels of pelagic primary pro- duction. The pulsed organic inputs to sediments resulting from spring and summer phytoplankton blooms at high latitudes may modulate carbon cycling, as well as many other processes such as animal growth, metabolism and selection for life histories on the sea floor (e.g. Clarke 1988, Grebmeier et al. 1988, Grebmeier \& McRoy 1989, Ambrose \& Renaud 1995, Barnes \& Clarke 1995, Piepenburg et al. 1997, Brockington et al. 2001). Moreover, much of the organic carbon deposited at high latitudes during the spring and summer 
bloom period may be respired under winter sea-ice cover, where $\mathrm{CO}_{2}$ efflux from sediments can be trapped beneath sea ice, entrained in newly forming deep waters, and advected into the ocean's interior (Yager et al. 1995). This mechanism could play an important role in the transfer of carbon from ocean surface waters to long-term deep-sea reservoirs.

The West Antarctic Peninsula (WAP) shelf is no exception to polar seasonal productivity patterns, experiencing highly seasonal vertical flux of particulate organic carbon (see Karl et al. 1996) from summer phytoplankton blooms in December to March, following the retreat of winter sea ice (e.g. R. C. Smith et al. 1996). Sediment-trap records from the Antarctic continental shelf suggest that sinking particle flux is orders of magnitude larger during summer than during icecovered winter months (Wefer et al. 1988, Dunbar et al. 1989, Honjo 1990). This dramatic productivity pulse is likely to result in deposition of labile food material for benthic detritivores.

While bacterioplankton biomass in the WAP region has been shown to increase by nearly 3 orders of magnitude during the summer bloom period (Karl et al. 1996), bacterial response to the summer bloom pulse has not been studied in Antarctic continental shelf sediments. The nature of the benthic microbial response to the short-lived (4 to $8 \mathrm{wk}$ long) summer bloom on the WAP shelf (e.g. Karl et al. 1996) is difficult to predict. Observed correlations in deep-sea sediments between microbial biomass and metabolism, and organic carbon rain rates (Meyer-Reil \& Koster 1992, Smith et al. 1997), suggest that bacterial abundance could increase in the WAP sediments during periods of particulate organic carbon (POC) deposition following the summer phytoplankton bloom. However, the consistently very low bottom-water temperatures in the WAP region $(-2.0$ to $1.0^{\circ} \mathrm{C}$ ) could slow microbial remineralization of phytodetritus deposited on the sea floor (Pomeroy \& Deibel 1986, Pomeroy et al. 1991). The combination of rapid particle sinking and low-temperature inhibition of microbial activity could lead to an accumulation of labile organic material in WAP sediments, resulting in a persistent 'food bank' for benthic detritivores over long time scales relative to the water column.

The purpose of this study was to evaluate temporal dynamics of 'labile' organic material in Antarctic continental shelf sediments, in an effort to test the 'food bank' hypothesis. We hypothesized that the intense seasonal particulate-flux signal observed in sediment-traps in this region would be damped in sediments due to rapid sinking and accumulation of phytodetritus on the sea floor, as well as temperature constraints on microbial metabolism. Under the food bank hypothesis, inventories of labile components of detritus were predicted to remain relatively constant throughout the year, such that benthic detritivores would experience substantially less seasonality in food availability than many pelagic organisms.

We conducted a seasonal time-series study on the WAP shelf, measuring sediment properties and particle flux to determine the timing and magnitude of bloom deposition on the sea floor, as well as the effects of seasonal deposition on microbial biomass, and the concentration and turnover times of labile organic material in sediments. The results presented here, including chloropigment, labile protein and microbial biomass data, provide evidence that labile organic pools persist on the WAP shelf over relatively long time scales of months to years (i.e. there is a sediment 'food bank'). We postulate a potential role of temperaturesubstrate limitation on microbial metabolism in promoting the occurrence of a sediment food bank.

\section{MATERIALS AND METHODS}

Study sites. Samples were collected on a series of five $22 \mathrm{~d}$ cruises to the WAP shelf. In order to explore both seasonal and interannual variability in particle flux and benthic ecosystem properties, cruises were conducted over a 15 mo period: Cruise I, November and December 1999 (austral summer pre-bloom season); Cruise II, March 2000 (end of summer bloom); Cruise III, June 2000 (winter oligotrophic period); Cruise IV, October 2000 (end of winter, during winter sea-ice retreat); Cruise V, February and March 2001 (during summer bloom). We sampled 3 stations (A, B, and C) on a NW to SE transect across the continental shelf from Anvers Island (Fig. 1, Table 1); 2 additional stations (E and F), located further south of this transect (Fig. 1, Table 1), were sampled only in March 2001, in order to place Stns A, B, and C in a broader regional context. Due to ice loading of the Antarctic continent, the continental shelf is generally depressed to depths in excess of $400 \mathrm{~m}$ (Anderson et al. 1984, Eisma 1988); water depth is approximately 500 to $650 \mathrm{~m}$ at all stations sampled here. Sonar and photographic surveys (C. Smith et al. unpubl. data) revealed little topographic relief at Stns B, C, E, and F. However, Stn A was located in a basin approximately $25 \mathrm{~km}$ wide, so topographic focusing could have impacted sediment processes in this area.

Field methods. On each cruise, sediment tube cores (10 cm diameter) were collected with a Bowers \& Connelly megacorer from each of at least 5 randomly located deployments at each station. Overlying water was siphoned off the top of each core, and the cores were sliced into 9 discrete horizontal layers down to $10 \mathrm{~cm}$, with finer $0.5 \mathrm{~cm}$ layers in the top $2 \mathrm{~cm}, 1.0 \mathrm{~cm}$ layers from 2 to $4 \mathrm{~cm}$, and $2 \mathrm{~cm}$ layers below $4 \mathrm{~cm}$ depth. When a phytodetrital layer (greenish flocculent material with fecal pellets and intact phytoplankton cells) was visible 

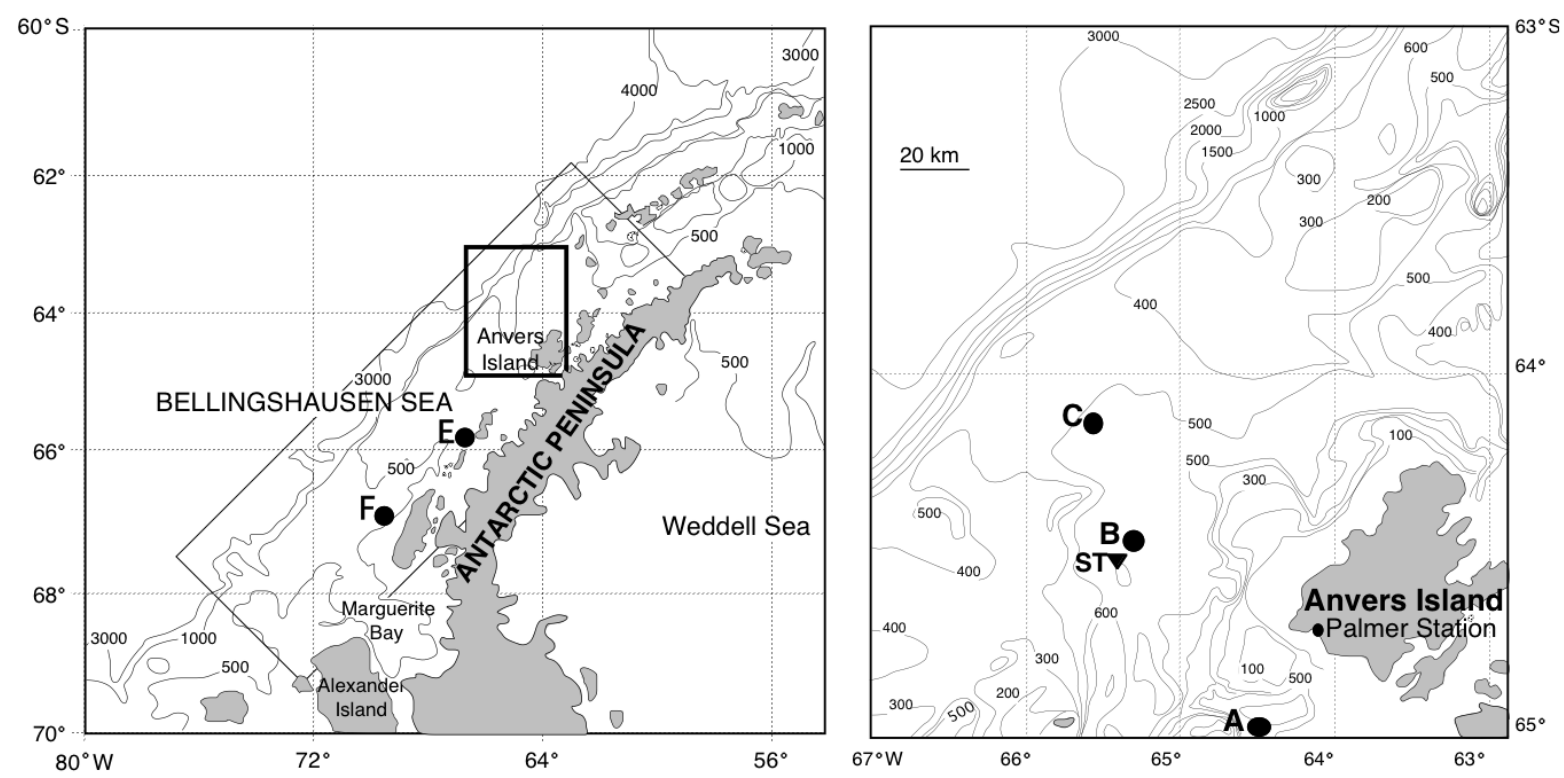

Fig. 1. Study area. ( Locations of Stns A, B, C (= transect) and E and F; $(\boldsymbol{\nabla})$ location of sediment-trap (ST) mooring

at the surface of a core (Cruise $\mathrm{V}$ only), it was removed with a large plastic syringe before core slicing, and stored for separate analysis. After slicing, each layer of sediment was homogenized and divided for analysis of chloropigments, labile protein, ATP and sediment dryweight determinations. Sediment samples for pigment analysis were immediately frozen at $-80^{\circ} \mathrm{C}$ and stored in the dark, while labile protein, ATP and dry-weight samples were frozen at $-20^{\circ} \mathrm{C}$.

Replicate, single-cup, cone-shaped sediment traps (cf. Dunbar et al. 1989) with effective mouth openings of $0.159 \mathrm{~m}^{2}$ were deployed on Cruise I (November 1999) at Stn B. Both traps were secured on a single mooring, 150 and $170 \mathrm{~m}$ above bottom. Traps were recovered and redeployed on each cruise (i.e. at 90 to 120 d intervals) until the final recovery in March 2001. Trap samples were preserved in situ with a hypersaline formalin solution ( $5 \% \mathrm{NaCl}$ w/w, $10 \%$ formalin by volume), and swimmers (in particular pelagic copepods) were removed upon sample recovery using a dissecting microscope. All samples were quantitatively split, and subsamples were allocated for various analyses.

Table 1. Position and water depth ranges of all stations sampled

\begin{tabular}{|lccc|}
\hline Stn & Latitude & Longitude & Depth (m) \\
\hline A & $65^{\circ} 10.32^{\prime} \mathrm{S}$ & $64^{\circ} 47.00^{\prime} \mathrm{W}$ & $550-625$ \\
$\mathrm{~B}$ & $64^{\circ} 48.00^{\prime} \mathrm{S}$ & $65^{\circ} 21.00^{\prime} \mathrm{W}$ & $585-600$ \\
$\mathrm{C}$ & $64^{\circ} 12.50^{\prime} \mathrm{S}$ & $65^{\circ} 21.90^{\prime} \mathrm{W}$ & -570 \\
$\mathrm{E}$ & $65^{\circ} 58.84^{\prime} \mathrm{S}$ & $67^{\circ} 17.26^{\prime} \mathrm{W}$ & -620 \\
$\mathrm{~F}$ & $66^{\circ} 54.08^{\prime} \mathrm{S}$ & $69^{\circ} 39.80^{\prime} \mathrm{W}$ & -680 \\
\hline
\end{tabular}

Laboratory methods. Sediment chloropigment concentrations were measured using a combination of high-performance liquid chromatography (HPLC) and fluorometric methods. Sediment-trap samples were quantitatively split, and 4 replicate splits from each sample were vacuum-filtered through $25 \mathrm{~mm} \mathrm{GF/F}$ filters. Wet filters were then placed into glass test tubes with $5 \mathrm{ml}$ of $100 \%$ HPLC grade acetone, and ground with a homogenizer. Frozen sediments were thawed, and subsamples were also placed in glass test tubes with $5 \mathrm{ml}$ of acetone. All samples were vortexed, sonicated in a dark ice bath for $10 \mathrm{~min}$, and extracted overnight in the dark at $-20^{\circ} \mathrm{C}$ (Sun et al. 1991). Extracted samples were then centrifuged at $3000 \mathrm{rpm}$ for $5 \mathrm{~min}$, and fluorescence of the extracts was measured at $670 \mathrm{~nm}$ using a Turner model 10-AU fluorometer. Each sample was extracted twice, since extraction efficiency tests indicated $>95 \%$ recovery after 2 extractions. Chloropigment and phaeopigment concentrations were calculated based on a pure chl a standard (Sigma Chemical Co.) and acidification. Values were normalized to salt-corrected dry weights of either sediment-trap particulate material or the extracted sediments.

For a subset of samples (1 to 3 cores station ${ }^{-1}$, cruise $^{-1}$, from phytodetritus and from sediment-trap samples), aliquots of the extracts obtained as described above were also analyzed using reverse-phase HPLC, in an effort to verify that fluorescence values accurately represented concentrations of chl a. The HPLC system consisted of a Varian 9300 autosampler and Varian 9012 HPLC. The column used was a $5 \mu \mathrm{m}$ particle ODS2-Spherisorb $(250 \times 4.6 \mathrm{~mm}$ inner diameter $)$. 
Detection was performed using ThermoSeparations Products UV2000 and FL2000 detectors and run at wavelengths of 436 and $450 \mathrm{~nm}$.

The presence of chlorophyll breakdown products or other fluorescent compounds can lead to inaccurate fluorometric measurements, particularly in sediments (Mantoura \& Llewellyn 1983, Mantoura et al. 1997). In this study, fluorometric methods were found to overestimate values of chl $a$, and correction factors were applied to fluorometry data to obtain more accurate values for chl a concentrations in sediments. Percent differences between HPLC and fluorometric values of chl a were calculated for each of the HPLC samples (which were previously analyzed with fluorometry). Mean differences were calculated for each station at each time point. Similar percentages were found for Stns B and C, and these were averaged together, giving 1 value for both these stations at each of the 5 time points. Percent differences were multiplied by the fluorometric values for samples analyzed by fluorometry only, in order to correct for overestimation by fluorometry. Only corrected values are presented here. Correction factors ranged from 0.40 for phytodetrital layers to 0.015 for some layers deeper than $5 \mathrm{~cm}$. Correction factors could not be obtained for sediment-trap material. Chl a was not detectable in sediment-trap HPLC samples because the formalin fixation altered elution times. Thus, it was assumed that $100 \%$ of sediment-trap fluorometric values represented chl a fluorescence, since algal material deposited in traps should consist mainly of relatively fresh, intact cells.

Enzymatically hydrolyzable amino acid (EHAA) analyses were performed on sediments to measure 'labile protein.' This assay measures an enzymatically degradable fraction of protein in sediments, which can comprise a relatively small percentage of the total protein pool (Dauwe et al. 1999, Dell'Anno et al. 2000, Danovaro et al. 2001). EHAA is thought to measure the pool of protein readily available as a food source for deposit-feeders (Mayer et al. 1995). Frozen sediments were freeze-dried prior to amino-acid extraction. Extractions and analyses were performed according to the methods of Mayer et al. (1995). Briefly, soluble amino acids were extracted from replicate freeze-dried sediment samples in a poisoned phosphate buffer. We incubated 1 set of replicates at $37^{\circ} \mathrm{C}$ with Proteinase-K to remove the enzyme-degradable fraction. Higher molecular weight peptides were removed from all extracts via trichloroacetic acid (TCA) precipitation. Amino acid concentrations were obtained using the fluorescence method, in which O-phthalaldialdehyde reagent was added to the lower molecular weight fraction of the extract, and fluorescence was measured on a Perkin-Elmer Model LS-5 fluorescence spectrophotometer at excitation/emission wavelengths of 340 and $455 \mathrm{~nm}$, respectively. Concentrations of soluble amino acids were subtracted from values for enzymedegraded samples to obtain EHAA concentrations. EHAA could not be measured on sediment-trap samples, because the formalin fixation interferes with the extraction procedure.

ATP concentrations were measured to estimate microbial biomass in sediments, although it should be noted that meiofauna can also contribute to the total ATP biomass. ATP analyses were performed according to the methods of Karl (1993). On shipboard, 6 replicate, fresh sediment samples $\left(1 \mathrm{~cm}^{3}\right)$ from each core slice were extracted in cold $0.5 \mathrm{M} \mathrm{H}_{3} \mathrm{PO}_{4}$. ATP internal standard was added to 3 of the 6 replicates to estimate adsorptive and other losses of extracted ATP (Karl \& Craven 1980, Karl 1993). All samples were centrifuged, and $500 \mu \mathrm{l}$ of supernatant was removed to microcentrifuge tubes. Tris buffer was added to each tube, and samples were frozen at $-80^{\circ} \mathrm{C}$. In the laboratory, samples were stored at $-20^{\circ} \mathrm{C}$ and thawed immediately prior to analysis. Once thawed, samples were combined with firefly-lantern extract (Sigma FLE-50) prepared in a mixture of $\mathrm{MgSO}_{4}$ and arsenate buffer. ATP in the extracts was then measured using the firefly luciferase-luciferin bioluminescence assay (Karl 1993).

Statistical analyses. Data were analyzed using the Statistical Package for the Social Sciences (SPSS) software. In order to test seasonal differences in inventories of chl a, EHAA, and ATP (mass $\mathrm{cm}^{-2}$ ), a 1-way analysis of variance (ANOVA) was performed for each measurement at each sampling site (Sokal \& Rohlf 1995). Because 9 discrete sediment depths were sampled with each sediment core, seasonal differences in profiles of chl a, EHAA, and ATP concentrations (mass ${ }^{-1}$ sediment dry wt) were analyzed using 2-factor repeatedmeasures ANOVA (cf. Brown et al. 1997). In all tests, each sediment core was treated as a separate subject, with depth as the repeated measures factor and season as the between-subjects factor (Sokal \& Rohlf 1995). Post hoc pair-wise comparisons (least significant difference method) were used with both 1-way and repeated-measures ANOVA to determine which specific seasonal interactions were significantly different.

Chlorophyll $a$ and EHAA degradation rate models. We used 2 different models to estimate the degradation rate constants for $\mathrm{chl} a$ and EHAA in the upper 3 to $10 \mathrm{~cm}$ of sediment.

In Model I, open-system, steady-state conditions were assumed for the ice-free summer bloom period of November 1999 to June 2000. The similarity of the mean chl a profiles across this time period (see Fig. 3), and the slight change in chl a inventory (see Fig. 4), indicate that chl a input to the sediments could essentially be considered constant during this period. Model II, a non-steady-state model, was used to model chl a 
degradation rates based on changes in vertical flux and sediment inventories of chl a throughout the sampling period. This model was only applicable for chl a because it requires an estimate of vertical flux, which could not be obtained from sediment traps for EHAA. Both models are applied for Stn B, since vertical flux values were well constrained by sediment traps at this location. The models were also applied at Stn C, with the assumption that vertical flux was similar to that at Stn B, given the similarity between these stations in other variables (see 'Results').

Under steady-state (summer) conditions, a commonly used diffusion-advection model (cf. Smith et al. 1993, Stephens et al. 1997, Fornes et al. 1999) could be applied to obtain degradation rate constants for chl a and EHAA from sediment concentration profiles of these materials in the top $3 \mathrm{~cm}$ of sediment. This depth interval was chosen because the top $3 \mathrm{~cm}$ of sediment were consistently within the oxic zone (Hartnett et al. 2005), and below $3 \mathrm{~cm}$ pigment and EHAA concentrations changed little with increasing depth (i.e. $\partial \mathrm{C} / \partial z$ was essentially zero). The model is described here in terms of chl a.

The steady-state distribution of solid-phase chl $a$ in diffusively mixed sediment, assuming constant porosity, is described by:

$$
\mathrm{d} C / \mathrm{d} t=D_{\mathrm{b}}\left(\partial^{2} C / \partial z^{2}\right)-S(\partial C / \partial z)-k C=0
$$

where $C$ is the concentration and $k$ the first-order degradation-rate constant of chl $a, t$ is time (yr), $z$ is depth in sediment $(\mathrm{cm}), D_{\mathrm{b}}$ is a bioturbation coefficient $\left(\mathrm{cm}^{2} \mathrm{yr}^{-1}\right)$, and $S$ is the sedimentation rate $\left(\mathrm{cm} \mathrm{yr}^{-1}\right)$. Applying boundary conditions: $C(z)=C_{0}$ at $z=0$, and $C \rightarrow 0$ as $z \rightarrow \infty$, leads to the following solution to Eq. (1):

$$
C=C_{0} \exp (-\alpha z)
$$

where $\alpha^{-1}$ is the 1/e penetration depth of chl a (the depth at which concentration decreases to 1/e) (e.g. Stephens et al. 1997). The 1/e penetration depth can be determined by curve fits to the chl a profiles, and related to $k$ and $D_{\mathrm{b}}$ by:

$$
\alpha=\left[S-\left(S^{2}+4 k D_{\mathrm{b}}\right)^{1 / 2}\right] / 2 D_{\mathrm{b}}
$$

$D_{\mathrm{b}}$ was calculated from profiles of excess ${ }^{234} \mathrm{Th}$ (McClintic 2002). $D_{\mathrm{b}}$ values for the periods of interest here ranged from 1.6 to $8.2 \mathrm{~cm}^{2} \mathrm{yr}^{-1}$. Modeling studies of excess ${ }^{234} \mathrm{Th}$ profiles (McClintic 2002) indicated nonlocal exchange only between the sediment-water interface and depths greater than those modeled here, so non-local exchange should have had very little effect on the shape of the chl $a$ and EHAA profiles within the top $3 \mathrm{~cm}$. Sediment accumulation rates are $\sim 30 \mathrm{~cm}$ kiloyear(kyr) ${ }^{-1}$ at Stns B and C and $\sim 130 \mathrm{~cm} \mathrm{kyr}^{-1}$ at Stn A (D. DeMaster et al. unpubl. data). Therefore, the upper limit of the bioturbation Peclet number, Pe (where
$\mathrm{Pe}=S L / D_{\mathrm{b}}$, and $L$ is the $3 \mathrm{~cm}$ depth scale of interest), is 0.24. A Pe $<1$ indicates that diffusion dominates the transport processes over the depth of interest, and advection (i.e. sedimentation rate, $S$ ) can be ignored (Boudreau 1997). Thus, Eq. (3) can be simplified to:

$$
\alpha=\left(k / D_{\mathrm{b}}\right)^{1 / 2}
$$

Mean $D_{\mathrm{b}}$ values from each station on each cruise (McClintic 2002), calculated for sediment cores collected concurrently with those used for chloropigment analysis, were used to estimate $k$ (Eq. 4) from the penetration depths determined by least-squares linear regression of log-linear plots of each chloropigment profile (Smith et al. 1993).

Model II is a simple box model, in which the inventory of chl $a$ in the top $10 \mathrm{~cm}$ of sediment at a given time point $\left(t_{1}\right)$ is assumed to be a function of the inventory at some previous time $\left(t_{0}\right)$, net vertical flux into the box since $t_{0}(F)$, and the degradation rate $(k)$ of material within the box. A modeling depth of $10 \mathrm{~cm}$ was chosen in order to include the maximum depths of nonlocal mixing, based on excess ${ }^{234} \mathrm{Th}$ profiles (McClintic 2002). This model was applied to sediments at Stn B, where sediment traps were deployed, because the vertical flux at this station could be relatively well constrained. However, results are also presented for Stn C since, as described in 'Results', similar patterns in chl a concentration were found at this station.

The rate of change in the inventory of chl $a$ in the top $10 \mathrm{~cm}$ at any given time can be described by:

$$
\mathrm{d} I / \mathrm{d} t=-k I+F
$$

where $I$ is the inventory size $\left(\mu \mathrm{g} \mathrm{chl} \mathrm{a} \mathrm{m}^{-2}\right)$ in the top $10 \mathrm{~cm}, t$ is time (d), $k$ is the first-order degradation rate constant $\left(\mathrm{d}^{-1}\right)$, and $F$ is the net flux of chl $a$ into the box (i.e. sediment-trap flux in, minus burial flux out, in $\mu \mathrm{g}$ $\mathrm{m}^{-2} \mathrm{~d}^{-1}$ ). Because burial flux of chl a was $<0.2 \%$ of sediment-trap flux (i.e. smaller than our error estimates for trap flux), burial flux was ignored as negligible. Solving this equation gives

$$
I=\left[\left(I_{0}-F / k\right) \exp (-k t)\right]+F / k
$$

Eq. (6) cannot be easily solved for $k$, so Matlab software was employed, using the $f_{0}$ function and iterative methods, to estimate values of $k$.

\section{RESULTS}

\section{Vertical flux and patterns of labile organic material in sediments}

In an effort to evaluate seasonal dynamics in the flux and fate of organic material in sediments, chl a flux to sediment traps was compared with temporal patterns 
in concentrations and inventories of chloropigments and EHAA in sediments. Chl a flux was about $21 \mu \mathrm{g}$ $\mathrm{m}^{-2} \mathrm{~d}^{-1}$ throughout the spring and summer sampling periods in 1999 to 2000, and declined during the winter

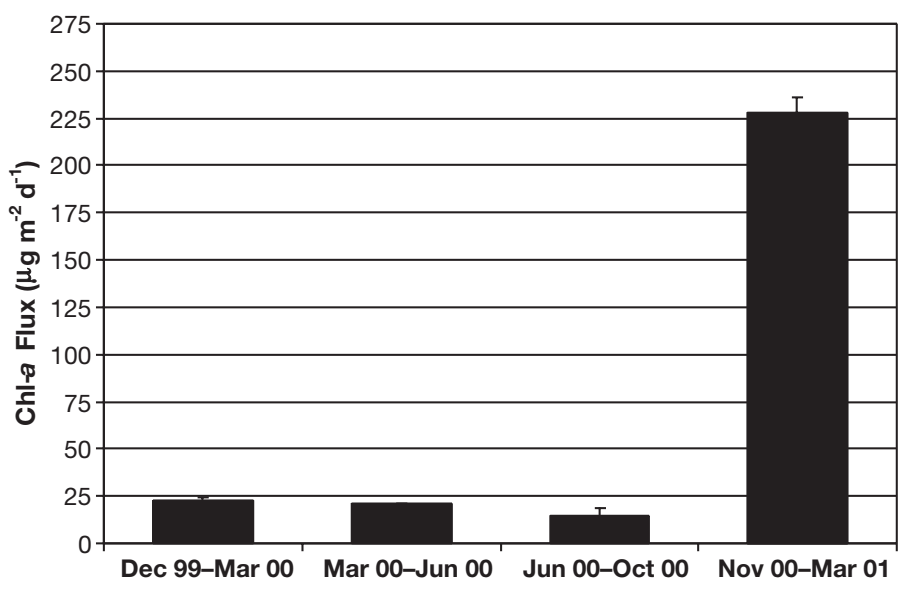

Fig. 2. Mean ( $\pm 1 \mathrm{SE})$ chlorophyll a mass flux $\left(\mu \mathrm{g} \mathrm{m} \mathrm{m}^{-2} \mathrm{~d}^{-1}\right)$ measured in 2 in-line sediment traps moored at 150 and $170 \mathrm{~m}$ above bottom at Stn B during spring and summer sampling periods in 1999 to 2001
(June to October 2000) to $14.5 \mu \mathrm{g} \mathrm{m}^{-2} \mathrm{~d}^{-1}$ (Fig. 2). A much larger flux event in the second summer season, between October 2000 and March 2001, yielded a summer $2001 \mathrm{chl}$ a flux of $227.5 \mu \mathrm{g} \mathrm{m}^{-2} \mathrm{~d}^{-1}$. This event also resulted in large interannual variability in phytodetrital accumulation between March 2000 and March 2001. While, at most, minimal phytodetritus appeared on the sediment surface during the first summer bloom period sampled (March 2000), in the following summer (March 2001), a thick phytodetrital carpet ( 1 to $5 \mathrm{~cm}$ ) was visible. Time-lapse photography indicates that phytodetrital deposition was greater throughout the 2000 to 2001 bloom season than in 1999 to 2000 (Suhr et al. 2003, Smith et al. 2005). The phytodetrital layer was removed from core surfaces and analyzed separately (Table 2).

Average chl a concentrations in sediment cores at each sampling time were similar between Stns B and C, and approximately 2 to 4 times higher for all sediment depths at Stn A (Fig. 3). Sedimentation at Stn A is likely to be influenced by the position of this station within a basin, which may cause focusing of sedimenting organic material. Indeed, a high sediment accumulation

Table 2. Average chlorophyll $a$, enzymatically hydrolytable amino acids (EHAA) and ATP concentrations, C:N ratios, porosity, and wt \% organic carbon in surface sediments $(0$ to $0.5 \mathrm{~cm})$ and phytodetritus (March 2001 only) for Sites A, B, C, E and F. Values are means $( \pm 1 \mathrm{SE})$ of 3 to 5 samples; where no errors are given, only 1 sample was analyzed. nd: no data

\begin{tabular}{|c|c|c|c|c|c|c|}
\hline Sampling date & $\begin{array}{c}\text { Chl } a \\
\left(\mu \mathrm{g} \mathrm{g}^{-1}\right)\end{array}$ & $\begin{array}{c}\text { EHAA } \\
\left(\mathrm{mg} \mathrm{g}^{-1}\right)\end{array}$ & $\begin{array}{c}\text { ATP } \\
\left(\mu \mathrm{g} \mathrm{g}^{-1}\right)\end{array}$ & $\begin{array}{c}\mathrm{C} / \mathrm{N} \\
\text { (wt/wt) }\end{array}$ & $\begin{array}{l}\text { Porosity } \\
\text { (vol/vol) }\end{array}$ & $\begin{array}{c}\% \text { org C } \\
(\mathrm{mg} / \mathrm{mg})\end{array}$ \\
\hline \multicolumn{7}{|l|}{ Site A } \\
\hline Nov 1999 & $1.29 \pm 0.2$ & $0.64 \pm 0.1$ & $2.27 \pm 0.4$ & $6.8 \pm 0.08$ & $0.74 \pm 0.02$ & $1.17 \pm 0.02$ \\
\hline Mar 2000 & $0.75 \pm 0.07$ & $0.70 \pm 0.07$ & $5.04 \pm 2.4$ & $6.8 \pm 0.05$ & $0.68 \pm 0.07$ & $1.34 \pm 0.01$ \\
\hline June 2000 & $0.94 \pm 0.07$ & $0.54 \pm 0.02$ & $9.49 \pm 3.05$ & $7.0 \pm 0.05$ & $0.67 \pm 0.1$ & $1.25 \pm 0.001$ \\
\hline Oct 2000 & $0.57 \pm 0.05$ & $0.62 \pm 0.1$ & $12.43 \pm 0.4$ & $6.7 \pm 0.2$ & $0.75 \pm 0.04$ & $1.26 \pm 0.06$ \\
\hline Mar 2001 & $3.07 \pm 0.6$ & $0.68 \pm 0.1$ & $4.00 \pm 1.2$ & $6.3 \pm 0.3$ & $0.71 \pm 0.1$ & $1.46 \pm 0.1$ \\
\hline Phytodetritus & $83.93 \pm 39.0$ & $1.00 \pm 0.3$ & $32.34 \pm 24.4$ & $5.9 \pm 0.6$ & $0.83 \pm 0.06$ & $1.70 \pm 0.3$ \\
\hline \multicolumn{7}{|l|}{ Site B } \\
\hline Nov 1999 & $0.32 \pm 0.07$ & $0.32 \pm 0.04$ & $2.08 \pm 0.8$ & $7.4 \pm 0.7$ & $0.80 \pm 0.05$ & $1.05 \pm 0.06$ \\
\hline Mar 2000 & $0.23 \pm 0.02$ & $0.45 \pm 0.05$ & $2.48 \pm 0.8$ & $6.7 \pm 0.1$ & $0.58 \pm 0.07$ & $1.03 \pm 0.02$ \\
\hline June 2000 & $0.17 \pm 0.03$ & $0.51 \pm 0.07$ & $1.57 \pm 1.3$ & nd & $0.60 \pm 0.07$ & nd \\
\hline Oct 2000 & $0.15 \pm 0.01$ & $0.58 \pm 0.03$ & $1.42 \pm 0.07$ & nd & $0.74 \pm 0.04$ & nd \\
\hline Mar 2001 & $0.72 \pm 0.2$ & $0.71 \pm 0.2$ & $3.58 \pm 1.04$ & $6.1 \pm 0.3$ & $0.77 \pm 0.03$ & $1.90 \pm 0.7$ \\
\hline Phytodetritus & $4.95 \pm 0.9$ & $1.27 \pm 0.2$ & $42.29 \pm 8.1$ & $6.2 \pm 0.03$ & $0.80 \pm 0.07$ & $1.14 \pm 0.08$ \\
\hline \multicolumn{7}{|l|}{ Site C } \\
\hline Nov 1999 & $0.45 \pm 0.06$ & $0.51 \pm 0.02$ & $1.99 \pm 0.7$ & $6.8 \pm 0.2$ & $0.67 \pm 0.04$ & $1.11 \pm 0.08$ \\
\hline Mar 2000 & $0.24 \pm 0.03$ & $0.64 \pm 0.09$ & $2.29 \pm 0.5$ & $6.7 \pm 0.01$ & $0.81 \pm 0.04$ & $1.09 \pm 0.07$ \\
\hline Jun 2000 & $0.31 \pm 0.04$ & $0.44 \pm 0.09$ & $5.31 \pm 2.8$ & $6.5 \pm 0.06$ & $0.65 \pm 0.06$ & $1.07 \pm 0.03$ \\
\hline Oct 2000 & $0.13 \pm 0.02$ & $0.46 \pm 0.04$ & $1.85 \pm 0.7$ & $6.6 \pm 0.06$ & $0.81 \pm 0.03$ & $0.97 \pm 0.03$ \\
\hline Mar 2001 & $0.79 \pm 0.2$ & $0.57 \pm 0.09$ & $5.77 \pm 2.5$ & 6.0 & $0.82 \pm 0.03$ & 1.19 \\
\hline Phytodetritus & $1.42 \pm 0.3$ & $0.64 \pm 0.3$ & $19.76 \pm 13.3$ & 5.7 & $0.83 \pm 0.1$ & $0.93 \pm 0.002$ \\
\hline \multicolumn{7}{|l|}{ Site E } \\
\hline Mar 2001 & $1.12 \pm 0.7$ & nd & nd & nd & 0.90 & nd \\
\hline Phytodetritus & $8.53 \pm 3.7$ & nd & nd & nd & 1.01 & nd \\
\hline \multicolumn{7}{|l|}{ Site F } \\
\hline Mar 2001 & $0.37 \pm 0.07$ & nd & nd & nd & $0.89 \pm 0.2$ & nd \\
\hline Phytodetritus & $2.17 \pm 0.2$ & nd & nd & nd & $0.84 \pm 0.03$ & nd \\
\hline
\end{tabular}




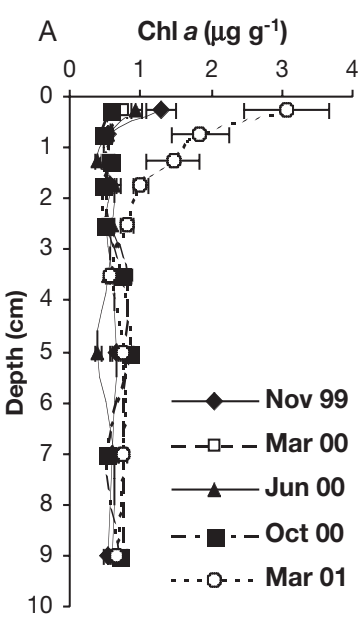

B

Chl a $\left(\mu \mathrm{g} \mathrm{g}^{-1}\right)$

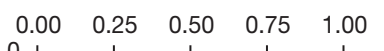

$0_{1}^{0.00 \quad 0.25 \quad 0.50 \quad 0.75} 1.00$$$
1
$$$$
2
$$

3
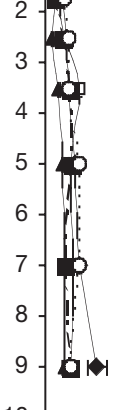

10

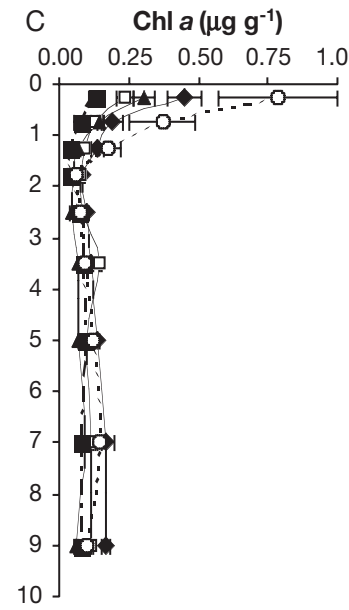

Fig. 3. Sediment chlorophyll a concentration ( $\mu \mathrm{g} \mathrm{g}^{-1}$ sediment dry wt) in top $10 \mathrm{~cm}$ at (A) Stn A, (B) Stn B, and (C) Stn C. Concentration in phytodetritus is not included in surface-sediment value. Note that concentration scale for (A) differs from that of (B) and (C). Data are plotted at the midpoint of the depth interval sampled. Each profile represents mean $( \pm 1 \mathrm{SE})$ concentration $(\mathrm{N}=5)$
Inventories of chl a $\left(\mu \mathrm{g} \mathrm{chl} a \mathrm{~cm}^{-2}\right.$ of sediment surface) in the top $10 \mathrm{~cm}$ of sediment varied significantly across time at all stations (Stn A: $F=9.979$, $\mathrm{p}<0.001 ; \mathrm{B}: F=19.833, \mathrm{p}<0.001 ; \mathrm{C}$ : $F=3.322, p=0.029$ ) (Fig. 4). At Stns B and $\mathrm{C}$, chl a inventories declined slightly from November 1999 through March 2000, yielding late summer values about $25 \%$ lower than spring values. Post hoc tests indicate significant differences only between particular seasons. At Stn B, spring (November 1999) and late summer (March 2000 and March 2001) chl a inventories were significantly higher than winter (June and October 2000) inventories. The 2 successive summers also differed significantly from each other, indicating strong interannual variability. At Stn C, rate at this station $\left(130 \mathrm{~cm} \mathrm{kyr}^{-1}\right)$ relative to the outer 2 stations, B and C (30 $\left.\mathrm{cm} \mathrm{kyr}^{-1}\right)$ (D. DeMaster et al. unpubl. data), provides further evidence of sediment focusing. Rapid sedimentation and shallower oxygen penetration depths at Stn A (Hartnett et al. 2005) could also result in higher preservation efficiencies at this station (Hartnett et al. 1998). Stns E and F were only sampled in March 2001, but chl a concentrations were comparable to those at Stns B and C (Table 2).

Chl a concentrations at all stations remained relatively constant throughout the year, with most temporal variability confined to the top $2 \mathrm{~cm}$ of sediment (Fig. 3). Concentrations in March 2001 in the top $\mathrm{cm}$ of sediment were 3 times higher than in the previous summer (March 2000) at Stns B and C, and nearly 4 times higher at Stn A, coincident with the presence of phytodetritus (not included in sediment profiles; Table 2). Repeated-measures ANOVA indicated significant temporal changes in the depth distribution of chl a at all three stations (Stn A: $F=4.967, \mathrm{p}=0.001$; B: $F=6.897, \mathrm{p}<0.001 ; \mathrm{C}: F=5.446, \mathrm{p}=0.001)$. At Stn A, post hoc comparisons indicated significantly higher concentrations in March 2001 (high-flux summer) than in any of the previous 4 sampling periods. At Stns B and C, significant pair-wise differences were found between summer and winter seasons, and between the 2 successive summers (March 2000 and March 2001).
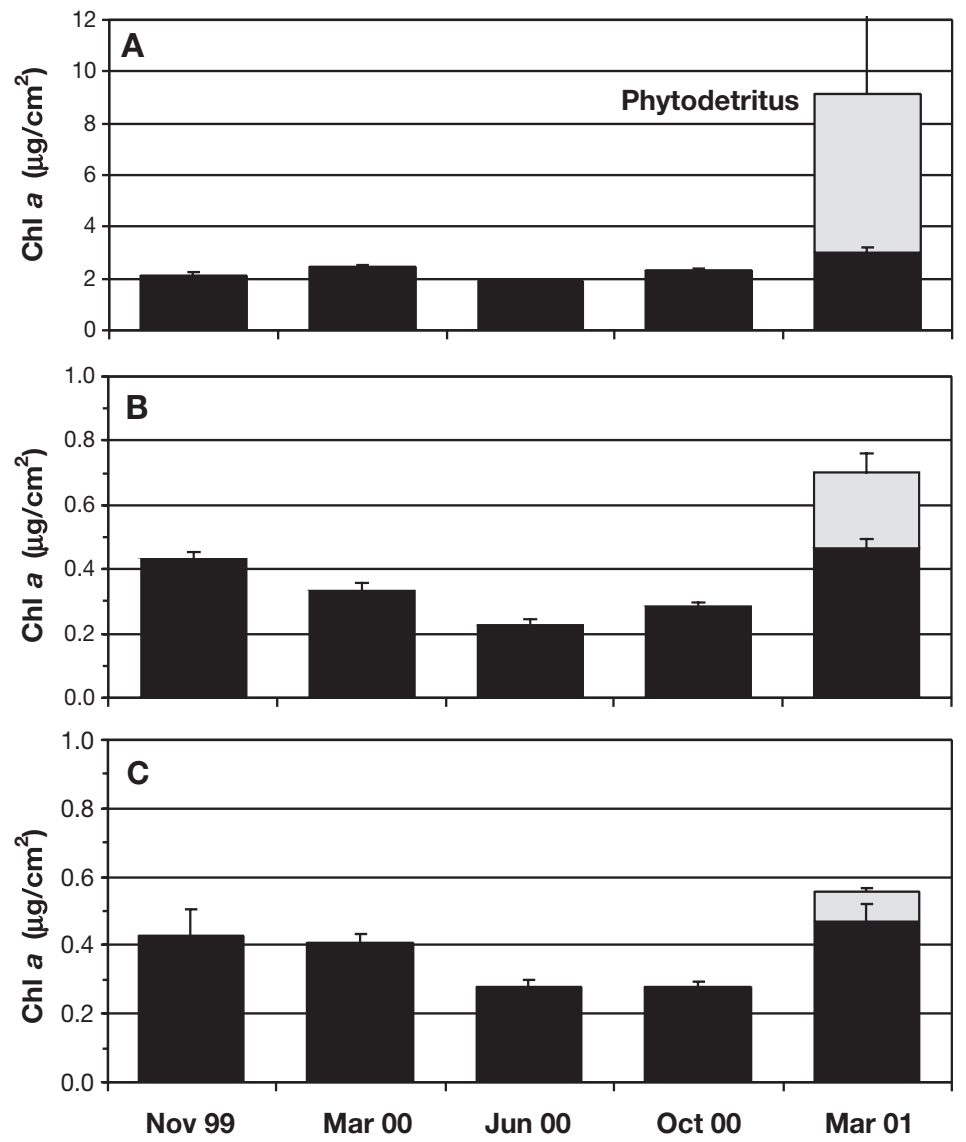

Fig. 4. Inventory of mean $( \pm 1 \mathrm{SE})$ chlorophyll a $\left(\mu \mathrm{g} \mathrm{cm}^{-2}\right)$ in top $10 \mathrm{~cm}$ of sediment at (A) Stn A, (B) Stn B, and (C) Stn C. Grey portion of March 2001 bar in each graph represents $\mu \mathrm{g} \mathrm{chl} \mathrm{a} \mathrm{cm}^{-2}$ in phytodetrital layer. Note that scale of ordinate in (A) differs from that in (B) and (C). N = 5 cores per time point 
inventories were significantly different between spring (November 1999) and winter (June and October 2000), and between winter (June and October 2000) and the following summer (March 2001). Seasonality was less pronounced at Stn A (Fig. 4), and sediment inventories (excluding phytodetritus) remained nearly constant yearround. Post hoc tests verify this pattern, with significant differences occurring only between March 2000 and June 2000, and between June 2000 and March 2001. The same trends in inventory size appear when considering only the top $2 \mathrm{~cm}$, or the top $4 \mathrm{~cm}$ of sediment (data not shown).

Chl a penetrated deeply into sediments, with concentrations at 8 to $10 \mathrm{~cm}$ ranging from 10 to $50 \%$ of surface values (Fig. 3). The presence of such a readily degradable organic compound at depth suggests substantial preservation of labile material in these sediments. Modeling results indicate a low degradation rate constant ( $k$ ) for chl $a$, implying that chl $a$ is retained in these sediments for relatively long periods of time (Table 3). The steady-state model, based on vertical profiles of chl $a$, yielded values of $k$ ranging from 0.6 to $4.6 \mathrm{yr}^{-1}$ at Stns B and $\mathrm{C}$. These $k$ s yield chl $a$ half-lives $\left(t_{1 / 2}\right)$ for the top $3 \mathrm{~cm}$ of sediment on the order of 50 to $400 \mathrm{~d}$ for the icefree spring and summer months at Stns B and C. The non-steady-state model, based on changes in inventory in the top $10 \mathrm{~cm}$, yielded comparable results, with $k$ for the first year ranging from a summer 2000 high of about $4 \mathrm{yr}^{-1}$ to a winter low of about $1.5 \mathrm{yr}^{-1}$ (Table 3). $\mathrm{Chl}$ a half-lives derived from these values of $k$ range
Table 3. Results of chlorophyll a and EHAA degradation rate models. Model I (open-system, steady-state) is based on concentration profiles of chl a and EHAA for top $3 \mathrm{~cm}$ of sediment for spring and summer 1999 and 2000. Model II (non-steady-state box-model) on sediment-trap fluxes and inventories of chl a for top $10 \mathrm{~cm}$ of sediment for spring and summer of 1999 to $2001 . D_{\mathrm{b}}$ : bioturbation rates $\left(\mathrm{cm}^{2} \mathrm{yr}^{-1}\right)$ obtained from profiles of excess ${ }^{234} \mathrm{Th}\left({ }^{234} \mathrm{Th}_{\mathrm{xs}}\right)$ in top $3 \mathrm{~cm}$ of sediment (used only for Model I calculations of degradation rate constants, $k$ ). Model I values are means $\pm 1 \mathrm{SE}(\mathrm{N}=3$ to 5$)$. na: not applicable

\begin{tabular}{|c|c|c|c|c|c|}
\hline Model & Parameter & Date & $D_{\mathrm{b}}$ & $k\left(\mathrm{yr}^{-1}\right)$ & $t_{1 / 2}(\mathrm{yr})$ \\
\hline \multicolumn{6}{|l|}{ Model I } \\
\hline \multirow[t]{2}{*}{ Stn B } & Chl a & $\begin{array}{l}\text { Nov } 99 \\
\text { Mar } 00 \\
\text { Jun } 00\end{array}$ & $\begin{array}{l}6.09 \pm 3.91 \\
2.93 \pm 0.062 \\
5.72 \pm 2.55\end{array}$ & $\begin{array}{l}2.49 \pm 0.38 \\
1.20 \pm 0.004 \\
4.33 \pm 0.16\end{array}$ & $\begin{array}{l}0.28 \pm 0.12 \\
0.58 \pm 0.18 \\
0.16 \pm 0.02\end{array}$ \\
\hline & EHAA & $\begin{array}{l}\text { Nov } 99 \\
\text { Mar } 00 \\
\text { Jun } 00\end{array}$ & $\begin{array}{l}6.09 \pm 3.91 \\
2.93 \pm 0.062 \\
5.72 \pm 2.55\end{array}$ & $\begin{array}{l}0.45 \pm 0.094 \\
0.15 \pm 0.004 \\
0.19 \pm 0.14\end{array}$ & $\begin{array}{l}1.54 \pm 0.31 \\
4.50 \pm 3.75 \\
3.68 \pm 11.52\end{array}$ \\
\hline \multirow[t]{2}{*}{ Stn C } & Chl a & $\begin{array}{l}\text { Nov } 99 \\
\text { Mar } 00 \\
\text { Jun } 00\end{array}$ & $\begin{array}{r}10.03 \pm 4.97 \\
3.12 \pm 0.95 \\
6.19 \pm 4.14\end{array}$ & $\begin{array}{l}4.57 \pm 0.41 \\
0.57 \pm 0.05 \\
4.59 \pm 0.27\end{array}$ & $\begin{array}{l}0.15 \pm 0.06 \\
1.21 \pm 0.27 \\
0.15 \pm 0.03\end{array}$ \\
\hline & EHAA & $\begin{array}{l}\text { Nov } 99 \\
\text { Mar } 00 \\
\text { Jun } 00\end{array}$ & $\begin{array}{r}10.03 \pm 4.97 \\
3.12 \pm 0.95 \\
6.19 \pm 4.14\end{array}$ & $\begin{array}{c}0.28 \pm 1.26 \\
0.043 \pm 0.041 \\
1.25 \pm 1.13\end{array}$ & $\begin{array}{c}2.50 \pm 4.32 \\
16.09 \pm 15.82 \\
0.56 \pm 1.72\end{array}$ \\
\hline \multicolumn{6}{|c|}{ Model II } \\
\hline Stn B & Chl a & $\begin{array}{l}\text { Nov 99-Mar } 00 \\
\text { Mar 00-Jun } 00 \\
\text { Jun } 00-\text { Oct } 00 \\
\text { Oct } 00-\text { Mar } 01\end{array}$ & $\begin{array}{l}\text { na } \\
4.56 \\
1.42 \\
11.53\end{array}$ & $\begin{array}{l}3.25 \\
0.15 \\
0.49 \\
0.06\end{array}$ & 0.21 \\
\hline Stn C & Chl a & $\begin{array}{l}\text { Nov } 99-\text { Mar } 00 \\
\text { Mar } 00-\text { Jun } 00 \\
\text { Jun } 00-\text { Oct } 00 \\
\text { Oct } 00-\text { Mar } 01\end{array}$ & $\begin{array}{l}\text { na } \\
3.87 \\
1.90 \\
14.78\end{array}$ & $\begin{array}{l}2.15 \\
0.18 \\
0.37 \\
0.05\end{array}$ & 0.32 \\
\hline
\end{tabular}

from about 55 to $180 \mathrm{~d}$. The large flux event in summer 2000 to 2001 (October to March) resulted in a larger $k$ ( 11 to $\left.15 \mathrm{yr}^{-1}\right)$, giving a chl a half-life of about $20 \mathrm{~d}$.

EHAA concentrations were similar between Stns B and $\mathrm{C}$, and only slightly higher at Stn A (Fig. 5), in contrast to the substantial difference in chl a concentrations between stations. EHAA concentrations varied little with season, although at Stn B, values were lower
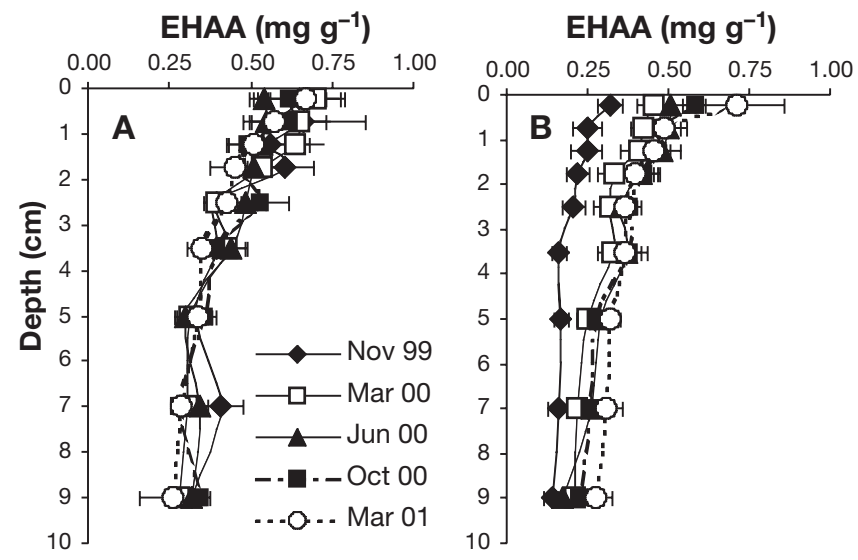

EHAA $\left(\mathrm{mg} \mathrm{g}^{-1}\right)$

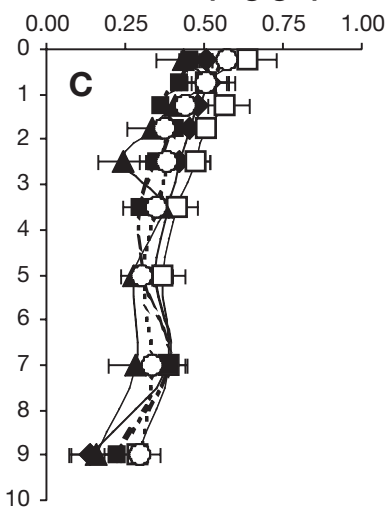

Fig. 5. Sediment EHAA concentration ( $\mathrm{mg} \mathrm{g}^{-1}$ sediment dry wt) in top $10 \mathrm{~cm}$ at (A) Stn A, (B) Stn $B$, and (C) Stn C. Concentration in phytodetritus is not included in surface-sediment value. Data are plotted at the midpoint of the depth interval sampled. Each profile represents mean $( \pm 1 \mathrm{SE})$ concentration ( $\mathrm{N}=3$ to 5$)$ 

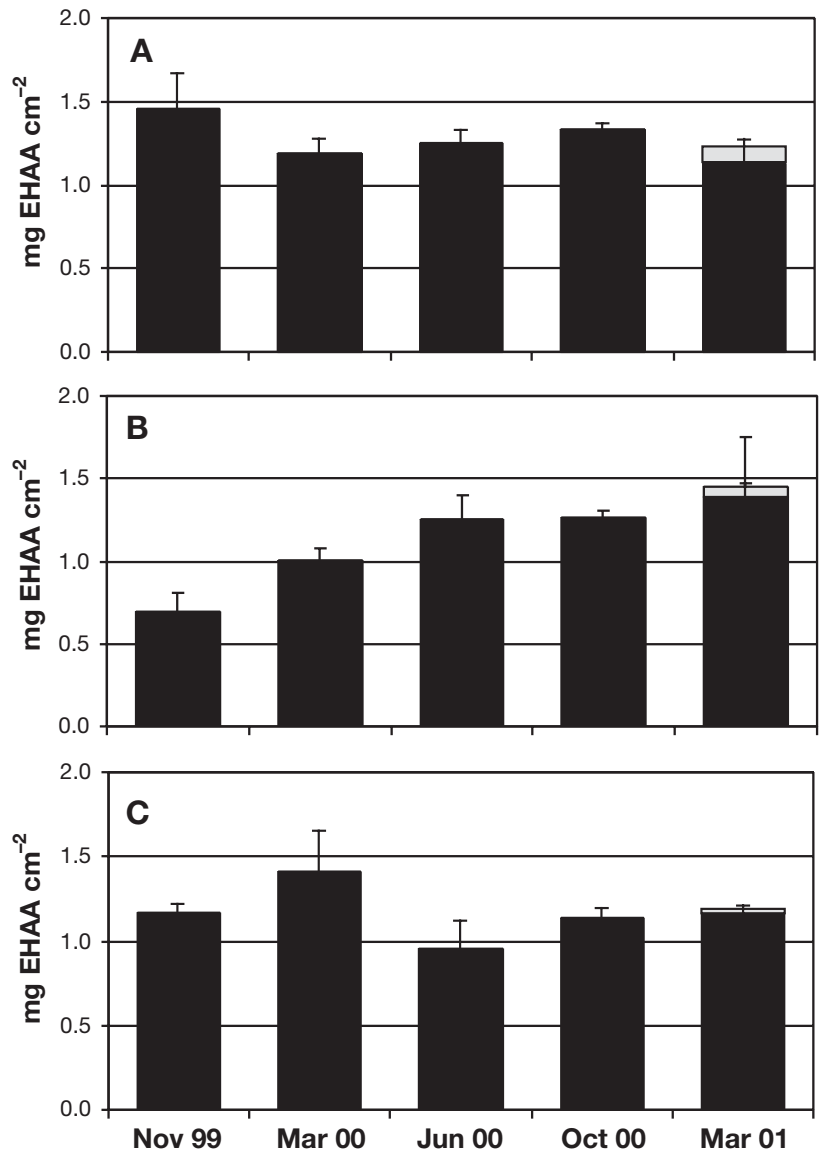

Fig. 6. Inventory of mean $( \pm 1 \mathrm{SE})$ EHAA $\left(\mathrm{mg} \mathrm{cm}^{-2}\right)$ in top $10 \mathrm{~cm}$ of sediment at (A) Stn A, (B) Stn B, and (C) Stn C. Grey portion of March 2001 bar in each graph represents mg EHAA $\mathrm{cm}^{-2}$ in phytodetrital layer. $\mathrm{N}=3$ to 5 cores per time point

in November 1999 than at any other period. The interannual variability observed in the chl a concentrations between March 2000 and March 2001 was largely absent from profiles of EHAA concentration, with the exception of Stn B, where a $50 \%$ increase was ob- served only in the surface layer (Fig. 5). EHAA inventories over the top $10 \mathrm{~cm}$ of sediment remained high year-round, and in general showed no statistically significant differences between seasons (Fig. 6). Results of 1-way ANOVA indicated statistically significant seasonal differences in EHAA inventory only at Stn B $(F=4.274, \mathrm{p}=0.013)$, with post hoc tests revealing inventories in November 1999 (spring) to be significantly lower than in June 2000, October 2000, and March 2001.

Modeling results for EHAA degradation yielded rate constants $(k)$ ranging from 0.04 to $1.25 \mathrm{yr}^{-1}$ in the spring and summer at Stns B and C (Table 3). Values were similarly low at both stations, giving EHAA halflives for ice-free seasons on the order of 6 mo to $16 \mathrm{yr}$.

\section{Microbial biomass}

ATP was measured in sediments and phytodetritus as an indicator of microbial biomass. Concentrations of ATP indicated very low microbial biomass below sediment depths of 3 to $4 \mathrm{~cm}$ (Fig. 7). ATP concentrations at most depths changed very little with season at Stns B and $C_{\text {; }}$ however, surface-layer values at Stn C in June 2000 and March 2001 were more than double values in other seasons. No statistically significant differences were detected at Stn B. At Stn C, October 2000 was significantly $(p<0.05)$ lower than at the other 4 times sampled. At Stn A, microbial biomass in the top $4 \mathrm{~cm}$ was lowest in spring and summer (November 1999 and March 2000), increasing steadily through the winter to a maximum in October 2000. Significant differences $(p<0.05)$ in ATP concentration profiles were detected at Stn A, with November 1999 less than June 2000, and June 2000 less than March 2001. Biomass concentrations in surface sediments did not show the same interannual variability as chl $a$, with ATP concentrations similar in March 2000 and March 2001 (Fig. 7). However, note that the concentration of microbial biomass
Fig. 7. Sediment ATP concentration $\left(\mu \mathrm{g} \mathrm{g} \mathrm{g}^{-1}\right.$ sediment dry wt) in top $10 \mathrm{~cm}$ at (A) Stn A, (B) Stn B, and (C) Stn C. Note that concentration scale for (A) differs from that in (B) and $(\mathrm{C})$. Data are plotted at the midpoint of the depth interval sampled. Each profile represents mean $( \pm 1$ SE) concentration ( $\mathrm{N}=4$ to 5$)$

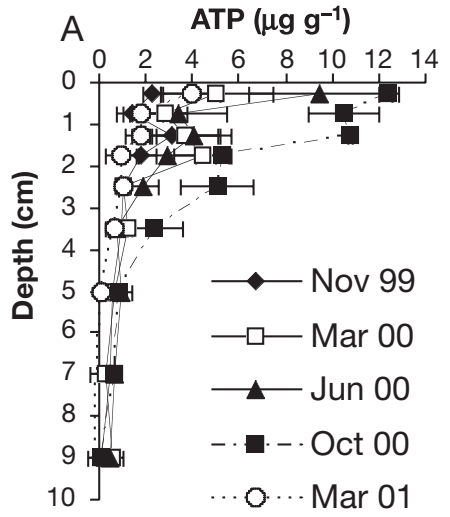

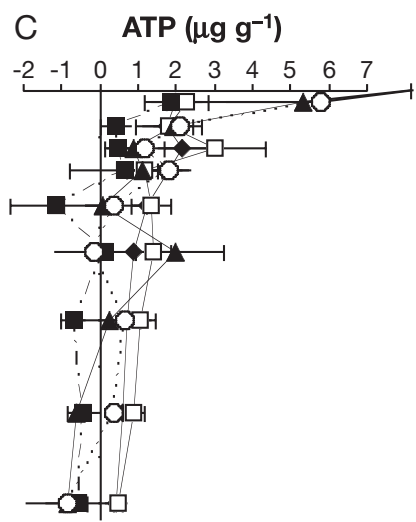


in March 2001 in the phytodetrital layer was between 4 and 10 times higher than in surface sediments at all stations (Table 2).

ATP inventories within the sediments (i.e. excluding phytodetritus) at Stn A were largest in the winter, increasing approximately 30\% from November 1999 to June 2000, and then declining steadily to about $50 \%$ of the June 2000 value by March 2001 (Fig. 8). ATP inventories showed a statistically significant seasonal trend at Stn A $(F=3.216, \mathrm{p}=0.036)$, with significant post hoc comparisons generally found between summer and winter. Again, despite the higher flux of chl a in March 2001, microbial biomass inventories within sediments were smaller in March 2001 than in the previous summer, suggesting a time lag between phytodetritus deposition and the buildup of peak microbial biomass within the sediments. However, when the contribution to the inventory of the phytodetrital layer in March 2001 is considered, values are comparable to these for March 2000. At Stns B and C, ATP inventories declined by about $80 \%$ from November 1999 to October 2000, and then increased again in March 2001, especially when the phytodetrital layer was included (Fig. 8). This trend mirrors that of the chl $a$ inventories at Stns B and C. Significant differences in inventory size were found at Stn C $(F=3.759, \mathrm{p}=0.024)$, with that for October 2000 less than those for both November 1999 and
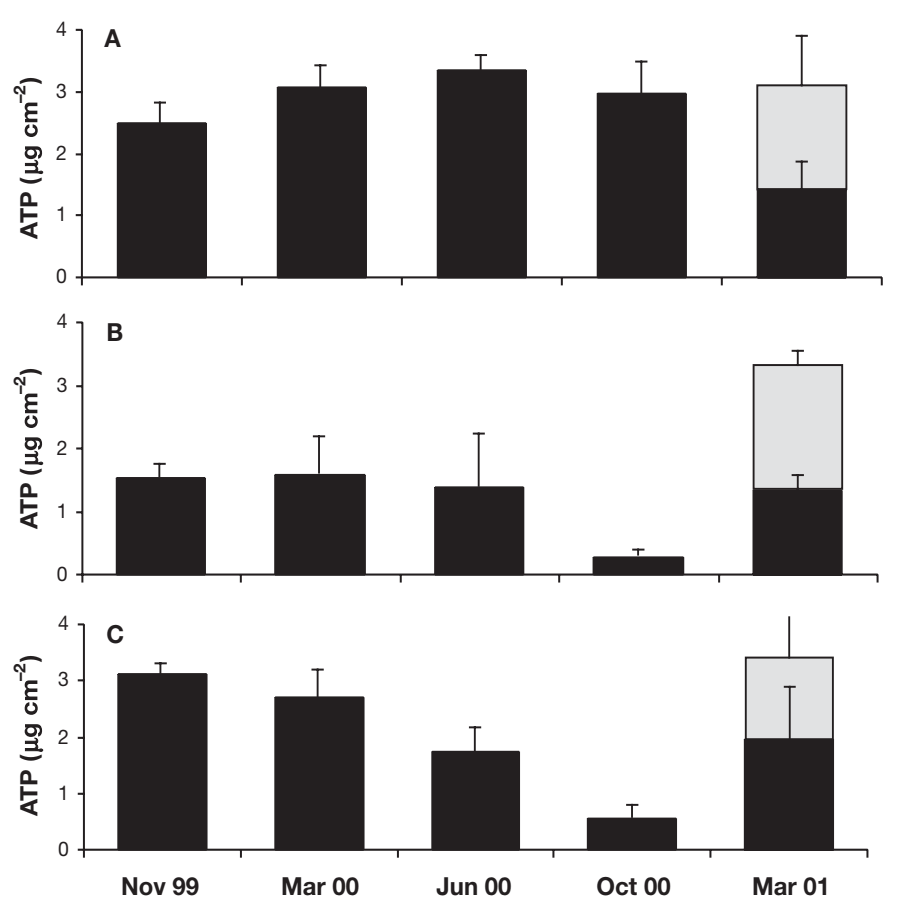

Fig. 8. Inventory of mean $( \pm 1 \mathrm{SE})$ ATP $\left(\mu \mathrm{g} \mathrm{cm}^{-2}\right)$ in top $10 \mathrm{~cm}$ at (A) Stn A, (B) Stn B, and (C) Stn C. Grey portion of the March 2001 bar in each graph represents $\mathrm{mg} \mathrm{ATP} \mathrm{cm}^{-2}$ in phytodetrital layer. $\mathrm{N}=4$ to 5 cores per time point
March 2000. No significant differences were found at Stn B, due to large within-site variance (Fig. 8). Notably, the presence of phytodetritus in March 2001 increased ATP inventories at all 3 primary stations (A, B and $\mathrm{C}$ ) in a pattern even more dramatic than for $\mathrm{chl} a$.

\section{DISCUSSION}

As anticipated, our results indicate significant seasonal variability in the vertical flux of chl a to the WAP shelf (Fig. 2). However, interannual differences in flux were far greater than seasonal differences during our study period. Despite the large temporal variability in flux, sea floor concentrations and inventories of labile compounds such as chl $a$ and EHAA varied modestly, particularly below the top few centimeters of sediment. Microbial biomass also varied only slightly with season, with most of the variability confined to the top 3 to $4 \mathrm{~cm}$ and the phytodetrital layer. Further, the large flux event in summer of 2000 to 2001 had not stimulated a concomitant increase in sediment microbial biomass by the time of our sampling in late summer (March) 2001.

\section{Evidence of sediment 'food bank'}

To evaluate the presence of a sediment food bank, it is necessary to compare changes in sediment inventories with the high temporal variability in particle flux to the WAP shelf. Sediment traps deployed during this study yielded seasonal flux estimates ranging from $1.2 \mathrm{mmol} \mathrm{C}_{\text {org }} \mathrm{m}^{-2} \mathrm{~d}^{-1}$ in summer 1999 to $0.5 \mathrm{mmol} \mathrm{C}_{\text {org }}$ $\mathrm{m}^{-2} \mathrm{~d}^{-1}$ in winter 2000 (Smith et al. 2005), and chl a fluxes varied similarly with season. However, interannual variability between the 2 summer bloom periods sampled was even greater than seasonal variability, with a 5-fold difference in $\mathrm{C}_{\text {org }}$ flux (Smith et al. 2005) and a more than 10-fold difference in chl a flux (Fig. 2) between March 2000 and March 2001. Comparison of shallow (D. Karl et al. unpubl. data) versus our deepmoored sediment trap fluxes indicates very little recycling of surface production in the water column between 150 and $450 \mathrm{~m}$ depth on the WAP shelf. Thus, the flux of summer bloom-derived phytodetritus is likely to constitute a relatively undegraded, yet temporally varying, input of food for shelf benthos.

Evidence of high-quality detritus rapidly reaching the deep shelf floor has been reported in other Antarctic studies (Dunbar et al. 1998, Fileman et al. 1998, Beaulieu 2002), and for numerous deep-sea sites (e.g. Billett et al. 1983, Lampitt 1985, C. R. Smith et al. 1996, Fabiano et al. 2001, Beaulieu 2002). Many studies, especially at mid-latitudes, have also demonstrated a coupling between pelagic and benthic processes, 
whereby benthic organic matter accumulation and metabolism are linked to flux events derived from phytoplankton blooms in the upper ocean (e.g. Gooday \& Turley 1990, Graf 1992, Ambrose \& Renaud 1995, Pfannkuche et al. 1999). We hypothesized that the coupling between phytodetritus deposition and mineralization would be relatively weak on the WAP shelf because phytodetritus would be rapidly mixed into sediments by active bioturbation, and degraded slowly (over periods of months) at the very low bottom-water temperatures on the Antarctic shelf, leading to storage of bloom material in a sediment food bank. If the food bank hypothesis is correct, labile organic matter pools in sediments should be present year-round, despite very low sinking organic flux from the water column during ice-covered winter months.

Profiles (Fig. 3) and inventories (Fig. 4) of chl a, a commonly used tracer of fresh phytoplankton biomass (Furlong \& Carpenter 1988, Sun et al. 1991, 1994, Stephens et al. 1997), indicate moderate seasonal changes in phytoplankton detritus in WAP sediments. Despite the high degree of interannual variability in particle flux (in particular, a thick phytodetrital carpet in March 2001), chl a concentrations in sediments below the top $1 \mathrm{~cm}$ varied little at most of our stations (Fig. 3). EHAA concentration profiles and inventories (Figs. $5 \& 6$ ) exhibited even less temporal variability than chloropigments; seasonal changes were minimal, and dramatic increases in EHAA concentrations beneath the phytodetrital layer in March 2001 were not observed. The proportion of the EHAA inventory contained in the phytodetrital layer was also quite small (Fig. 6). While inputs of fresh phytodetritus are often strongly correlated with chloropigment concentrations in sediments, our results and those of others suggest that labile protein accumulation is not necessarily strongly coupled to phytodetrital input (Fabiano et al. 2001, Demopoulos et al. 2003).

Chl $a$ and EHAA are not only available in sediments on the WAP shelf year-round, they are relatively enriched compared to other marine sediments. Chl a concentrations ranged from about 6 to $50 \mathrm{ng} \mathrm{g}^{-1}$ in surface sediments from the equatorial Pacific (C. R. Smith et al. 1996, Stephens et al. 1997), from 80 to $900 \mathrm{ng} \mathrm{g}^{-1}$ in North Carolina slope sediments (600 to $800 \mathrm{~m}$ ) (Cahoon et al. 1994), and from 100 to $150 \mathrm{ng} \mathrm{g}^{-1}$ in shallow $(28 \mathrm{~m})$ North Sea sediments during the summer maximum (Boon \& Duineveld 1998). These values are moderate to low compared to our values of 250 to $1000 \mathrm{ng} \mathrm{g}^{-1}$ for the WAP shelf, and for shelf stations in the Ross Sea, Antarctica (Fabiano \& Danovaro 1998). Baldwin \& Smith (2003) reported even higher chl a concentrations of 1000 to $14000 \mathrm{ng} \mathrm{g}^{-1}$ for surface sediments in the enclosed bay of Deception Island, Antarctica. However, these latter values were based solely on fluorometry, which may overestimate chl a concentration in sediments (Mantoura \& Llewellyn 1983, Mantoura et al. 1997).

EHAA values from surface sediments on the WAP shelf are also relatively high at 0.5 to $0.75 \mathrm{mg} \mathrm{g}^{-1}$, compared to a range of $\sim 0.1$ to $0.5 \mathrm{mg} \mathrm{g}^{-1}$ for samples from shelf depths in the North Sea, bathyal basins off California, and abyssal depths in the Porcupine Abyssal Plain (Dauwe et al. 1999, Dell'Anno et al. 2000, Danovaro et al. 2001, Demopoulos et al. 2003).

Persistence of chl $a$ and EHAA in WAP shelf sediments is increasingly apparent when the concentrations of these tracers are normalized to the organic carbon $\left(\mathrm{C}_{\text {org }}\right)$ content of the sediments. The chl a: $\mathrm{C}_{\text {org }}$ and EHAA: $\mathrm{C}_{\text {org }}$ ratios are moderate to high in WAP shelf sediments, with chl a: $\mathrm{C}_{\text {org }}$ reaching $10^{-4}$ in the top $1 \mathrm{~cm}$ of sediment. Chl $a: \mathrm{C}_{\text {org }}$ in Deception Island sediments was also on the order of $10^{-4}$ (Baldwin \& Smith 2003) although, as mentioned above, chl $a$ values in that study could have been substantially overestimated by fluorometric methods. While Demopoulos et al. (2003) found similar chl $a$ : $\mathrm{C}_{\text {org }}$ ratios in California's bathyal basins, their chl a concentrations were also based on fluorometry, and are thus likely to be overestimates as well. Chl a: $\mathrm{C}_{\text {org }}$ ratios in abyssal equatorial Pacific sediments, with $<1 \% \mathrm{C}_{\text {org }}$, were at least 1 order of magnitude smaller than in WAP shelf sediments, measuring about $2 \times 10^{-5}$ (C. R. Smith et al. 1996). EHAA: $\mathrm{C}_{\text {org }}$ ratios in WAP shelf surface sediments ranged from about 0.03 to 0.08, whereas Demopoulos et al. (2003) reported ratios up to 1 order of magnitude lower $(0.009$ to 0.02 ) in bathyal basins off California. EHAA: $\mathrm{C}_{\text {org }}$ at $280 \mathrm{~m}$ depths in the North Sea (0.019) also fell below WAP shelf values (Dauwe et al. 1999). These relatively high ratios in WAP sediments suggest that high proportions of depositing chl $a$ and EHAA are retained in surficial sediments in this region. The relatively low organic carbon content $(1 \%)$ in WAP shelf sediments appears to result from dilution of labile detritus by deposition of inorganic mineral components (McClintic 2002), rather than from rapid degradation of summer bloom detritus.

Unexpectedly, substantial chl a and EHAA concentrations were detected down to the deepest depths $(10 \mathrm{~cm})$ sampled in this study. Half-lives $\left(t_{1 / 2}\right)$ for $\mathrm{chl} a$ in oxic sediments vary widely, but laboratory experiments with shallow-water sediments have yielded values on the order of 10 to $30 \mathrm{~d}$ (Sun et al. 1993). However, much longer degradation half-lives (weeks to months) have been observed by other researchers in cold, and deep-water habitats (Stephens et al. 1997, Josefson et al. 2002). In the present study, the half-life of $\mathrm{chl} a$ in the sediment mixed layer ranged from roughly 50 to $200 \mathrm{~d}$ (Table 3), even in the oxic top $3 \mathrm{~cm}$ of sediment. ${ }^{14} \mathrm{C}$ measurements from this study also 
estimate labile carbon turnover times at 90 to $240 \mathrm{~d}$ (DeMaster et al. 2003). Some reports of long chl a halflives result from diagenetic modeling of deeper, anoxic sediments, where chl a degradation is slowed (e.g. Sun et al. 1993, Stephens et al. 1997). However, the chl a profiles modeled here only extended to $3 \mathrm{~cm}$, and were well within the oxygenated surface sediments (Hartnett et al. 2005). Alternatively, slow chl a degradation rates found on the WAP shelf may be related to low Antarctic bottom-water temperatures. Sun et al. (1993) reported a 4 -fold decrease in $k$ as experimental temperatures were lowered from 25 to $5^{\circ} \mathrm{C}$, with a half-life of $31 \mathrm{~d}$ at $5^{\circ} \mathrm{C}$. Thus, lower degradation rates might be expected on the WAP shelf, where bottom-water temperatures drop as low as $-1.8^{\circ} \mathrm{C}$.

Because degradation rates of EHAA have not been reported elsewhere, we cannot be certain that EHAA degradation in WAP sediments, with half-lives of months to years, is unusually slow (Table 3); however, the high EHAA concentrations and EHAA: $\mathrm{C}_{\text {org }}$ ratios suggest strongly that this is the case. While the EHAA assay is designed to simulate digestion in a depositfeeder gut, and is thought to extract the most 'labile' protein fraction (Mayer et al. 1995), the long half-lives indicate that EHAA may not be a sensitive measure of newly deposited phytoplankton detritus, at least in Antarctic shelf sediments. A study of detritivore food quality in California borderland basins also suggested different (e.g. slower) degradation dynamics for EHAA than for chl a (Demopoulos et al. 2003). Nonetheless, substantial evidence supports the usefulness of EHAA concentration as a measure of detritivore food quality, i.e. as an indicator of a sediment food bank (Mayer et al. 1995, Dauwe et al. 1999, Pusceddu et al. 2003). Thus, while EHAA appears to be a useful measure of the quantity of reactive organic material available as food to detritivores, seasonal variability in the vertical flux of EHAA associated with phytoplankton detritus is likely to be damped in WAP sediment inventories.

While some seasonal changes are evident in sediment chloropigment values, they are clearly less pronounced than interannual changes. Without additional sampling following the high-flux event in summer 2001, we cannot determine the long-term effects on sediment inventories of interannual, relative to seasonal, variability in particulate flux. However, fairly sizable pools of labile material do persist in WAP shelf sediments, indicating substantial sedimentary 'inertia' which dampens the effects of extreme temporal variability in productivity of the overlying waters. Normally labile material appears to degrade slowly in these sediments, such that unusually large flux events could have long-lasting effects on sediment inventories, producing a sediment food bank for detritivores.

\section{Microbial response to phytodetritus deposition}

Changes in microbial biomass inventories (Fig. 8) roughly mimicked those of chloropigment inventories (Fig. 4) at Stns B and C, with steady declines from a secondary maximum at the initial break-up of pack ice (November 1999) to a late-winter minimum (October 2000). This pattern suggests a stimulation of microbial growth by the summer bloom at these 2 outer stations, and a subsequent decline in biomass as labile material is degraded. In contrast, microbial biomass at Stn A exhibited a delayed response to the summer bloom, increasing steadily after the bloom and into the winter. This decoupling of vertical flux and microbial growth could be the result of non-seasonal inputs of organic material via lateral advection or topographic focusing in the relatively complex basin at Stn A.

While some seasonal changes in microbial biomass do occur in WAP shelf sediments, they are substantially smaller in magnitude than those occurring in the water column. Microbial biomass inventories varied seasonally in WAP shelf sediments by approximately 3 -fold or less, whereas bacterioplankton abundances in WAP surface waters increase as much as 6-fold from winter to summer months (Karl et al. 1996, Church et al. 2003).

Seasonal trends in microbial biomass at Stns B and C were not matched by sediment-community respiration rates, which showed no statistically significant seasonal variation (Thomas et al. unpubl. data). However, WAP shelf respiration rates were moderately high relative to those in other shelf and deep-sea settings (e.g. Gage \& Tyler 1991, Boon \& Duineveld 1998, Smith et al. 2001, Smith \& Demopoulos 2003), and roughly balanced the flux minus burial of sedimenting organic material (D. DeMaster et al. unpubl. data). Similar measurements in shallow Arctic and Antarctic waters also indicate a broad balance between carbon flux and benthic remineralization (Nedwell et al. 1993, Boon \& Duineveld 1998). Given this balance between POC flux and mineralization, as well as the presence of a large, metabolically active microbial community on the Antarctic shelf, why do pools of labile organic matter (e.g. chl $a$ and EHAA) persist at high concentrations?

\section{Temperature-substrate limitation hypothesis}

The persistence of large pools of labile organic matter in WAP sediments may be explained by a requirement for high substrate concentrations to drive microbial mineralization activities at very low temperatures (Pomeroy \& Deibel 1986, Wiebe et al. 1993, Nedwell 1999, Yager \& Deming 1999, Pomeroy \& Wiebe 2001). A number of studies have suggested that at low tempera- 
tures microbial communities may require higher substrate concentrations to sustain a particular level of heterotrophic activity (Pomeroy \& Deibel 1986, Pomeroy et al. 1991, Wiebe et al. 1992, 1993, Nedwell \& Rutter 1994, Arnosti et al. 1998, Arnosti \& Jørgensen 2003). Despite this evidence, the nature of temperature effects on microbial activity has remained controversial. Viable microbial communities are known to exist in glacial ice and permafrost soils, surviving at very low temperatures (down to $-40^{\circ} \mathrm{C}$ ) (e.g. Price \& Sowers 2004 and references therein). However, these communities survive through extremely low metabolic rates that are sufficient to maintain the cellular environment. Indeed, the potential for low temperatures to limit the rates of diffusion-dependent microbial processes seems intuitive (cf. Jumars et al. 1993). Despite the effects of temperature on microbial metabolism, sediment-community respiration rates in Antarctic sediments (e.g. Nedwell et al. 1993, Thomas et al. unpubl. data) are comparable to those in other bathyal and shelf environments (reviewed by Levin \& Gooday 2003 and Smith \& Demopoulos 2003). We propose a simple conceptual model whereby seemingly conflicting reports of high sediment-community respiration rates and low microbial activity in cold temperatures can be reconciled.

Organic material in marine sediments is largely composed of high molecular weight compounds not readily available for bacterial uptake, which must be hydrolyzed outside the cell by extracellular enzymes. We suggest that temperature effects on the activity of these enzymes can potentially limit microbial metabolic rates in Antarctic shelf sediments. According to substrate-addition experiments in natural, lowtemperature microbial communities, extracellular enzymatic hydrolysis is potentially rapid at high (i.e. saturating) concentrations of substrate, both in polar shelf sediments (Arnosti 1998, Arnosti et al. 1998, Fabiano \& Danovaro 1998) and in the deep sea (Meyer-Reil \& Koster 1992, Boetius \& Lochte 1996). Further, the temperature optima of at least some of the enzymes from permanently cold sediments are significantly higher than ambient environmental temperatures, and warming of the sediment greatly increases extracellular enzyme activity (EEA) at sub-saturating concentrations of substrate (Helmke \& Weyland 1991, MeyerReil \& Koster 1992, Nedwell \& Rutter 1994, Huston et al. 2000, Arnosti \& Jørgensen 2003, Bowman et al. 2003). Thus, it appears that extracellular hydrolysis is not inherently limited by low temperature if sufficient (i.e. high) levels of substrate are available.

A requirement for higher substrate concentrations at low temperatures suggests decreased affinity of extracellular enzymes for substrate binding, and/or reduced affinity of membrane-bound transport proteins for sub- strate uptake across cell membranes at low temperatures (Nedwell 1999). Enzyme affinity has been described for Antarctic bacteria using MichaelisMenten enzyme kinetics, which relates growth rate to substrate concentration (e.g. Nedwell \& Rutter 1994, Gerday et al. 1999). For Antarctic bacterial isolates, specific affinity for particular substrates, $a_{\mathrm{A}}^{\circ}$ (where $a_{\mathrm{A}}^{\circ}=\mu_{\max } K_{\mathrm{s}}^{-1}$, with $\mu_{\max }$ the maximum growth rate and $K_{\mathrm{s}}$ the Michaelis-Menten half-saturation constant), appears to decline with decreasing temperature (Nedwell \& Rutter 1994, Reay et al. 1999). These results, and similar data from some Arctic bacterioplankton (Yager \& Deming 1999), suggest an increased limitation of bacterially mediated mineralization rates by low substrate concentrations when temperatures are low.

It seems quite reasonable that microbial mineralization and respiration of a given type of organic substrate in sediments is limited by EEA, such that the rate of hydrolysis is a product of substrate concentration $(S)$ and a reaction-rate constant $(\kappa)$. Ultimately, total microbial heterotrophic activity is limited by the sum of the products of substrates and characteristic $\kappa$ s. In other words, sediment-community respiration, $R$, can be described by the equation $R \propto \sum\left(S_{i} \kappa_{i}\right)$, where $S_{i}$ and $\kappa_{i}$ are the respective concentrations and reaction-rate constants for the metabolizable components of the sediment organic matter. This formulation is conceptually identical to the oft-cited 'G-model' of Berner (1980), (Nedwell 1984) and the 'multi-B' model of Smith et al. (1994). The value of a particular $\kappa_{i}$ is related to enzyme efficiency, which, according to the above studies, decreases at low temperature. As a given $\kappa_{i}$ decreases due to lower temperatures, substrate conversion rate can be maintained for a given quantity of enzyme only by enhancement of substrate concentration $\left(S_{i}\right)$. Thus, we hypothesize that at low temperatures, a higher $S$ may be required to maintain a particular communitylevel rate of organic matter breakdown $(\kappa S)$ via enzymatic hydrolysis. WAP sediments might be thought of as operating at high average $S$ and low average $\kappa$ (Fig. 9), as might Arctic shelf sediments (note the strong negative relationship between temperature and sediment organic content in Glud et al.'s [1998] Arctic shelf data). The mineralization of organic matter in tundra soils appears to follow similar high-S, low-א dynamics (Schlesinger 1997). Low average $S$ and high $\kappa$, in contrast, would be characteristic of tropical and temperate sediments.

According to the temperature-substrate limitation hypothesis, the ability of bacteria to utilize organic material at low concentrations in sediments would be greatly reduced at the low temperatures typical of Antarctic shelf waters. Thus, organic matter would tend to build up in sediments until high enough substrate concentrations are achieved to allow community 


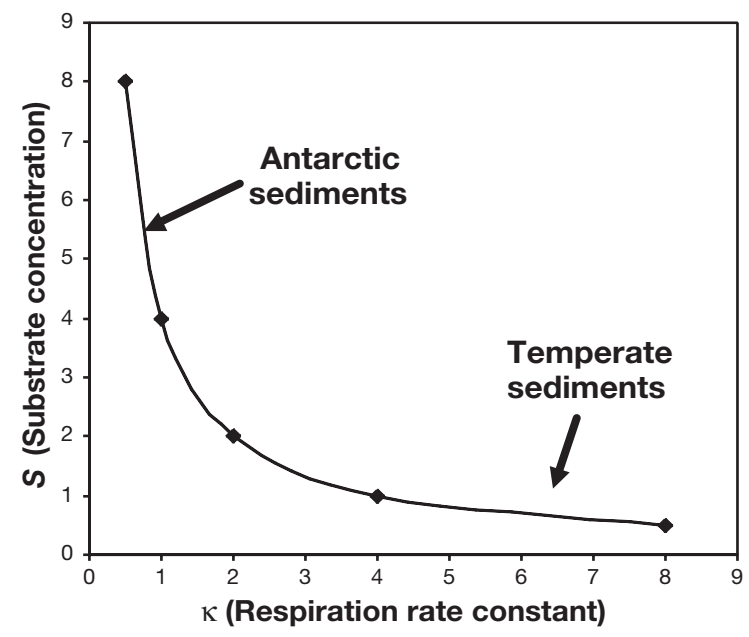

Fig. 9. Conceptual relationship between substrate concentration $(S)$ and degradation rate $(\kappa)$ in sediments. Line indicates constant respiration, which is a function of $S$ and $\kappa$. Antarctic sediments (permanently cold, high substrate concentration) function at high $S$, low $\kappa$, whereas temperate sediments (moderate temperature, low substrate concentration) function at low $S$, high $\kappa$. Each system can thus maintain equivalent respiration rate via different mechanisms

respiration to balance the sinking flux of labile POC. As a consequence, relatively high steady-state organic matter concentrations, such as those seen here for chl $a$ and EHAA, would be expected to accumulate in very cold sediments. Periodic deposition events should allow for short-term increases in microbial activity, while high background levels of organic matter persist in the long term. In temperate areas, total microbial community respiration rates may be equivalent, but concentrations of labile organic matter should be 'burned down' by microbial metabolism to lower steady-state levels. Further, a more intense response to organic flux events would be expected in temperate sediments, because pulses of labile organic material can be respired to lower concentrations.

The increasing steepness of the relationship between hydrolytic enzyme efficiency and temperature at very low temperatures $\left(<2^{\circ} \mathrm{C}\right)$ (e.g. Arnosti \& Jørgensen 2003) suggests that warming of Antarctic shelf bottom waters by a few degrees could significantly enhance the efficiency of microbial remineralization, decreasing background levels of labile organic material in sediments. This in turn could reduce food availability for benthic detritivores by decreasing the size of the 'food bank', altering food webs and reducing the rate of carbon sequestration in Antarctic shelf sediments. If the temperature-substrate limitation hypothesis is correct, continuation of the current trend of climate warming in the Antarctic Peninsula region (Smith et al. 2003) could have unexpectedly rapid impacts on benthic ecosystem function.
Acknowledgements. We sincerely appreciate the efforts of numerous cruise participants in sampling efforts, especially $\mathrm{T}$. Ferrero, N. Debenham, S. Suhr, E. Galley, A. Glover, P. Sumida, R. Jeffreys, A. Demopoulos, A. Baco-Taylor, E. Nelson, M. Parry, E. Ramirez and M. Baker. Additional thanks are given to A. Demopoulos, for her role in the adaptation of chlorophyll $a$ and EHAA analysis protocols. We also acknowledge the support of Raytheon Polar Services personnel, and the crews of the RV 'L. M. Gould' and RV 'N. B. Palmer'. We thank M. Landry, B. Popp, and D. Karl for use of equipment for laboratory analyses, and D. Karl, C. Thomas and H. Hartnett for access to unpubl. data. R. Bidigare and S. Christensen generously provided HPLC analyses. This project was supported by grants from the National Science Foundation, Office of Polar Programs to C.R.S. and D.J.D. This is contribution number 6637 from SOEST, University of Hawaii at Manoa.

\section{LITERATURE CITED}

Ambrose WG Jr, Renaud PE (1995) Benthic response to water column productivity patterns: evidence for benthicpelagic coupling in the Northeast Water Polynya. J Geophys Res 100(C3):4411-4421

Anderson JB, Brake CF, Myers NC (1984) Sedimentation on the Ross Sea continental shelf, Antarctica. Mar Geol 57(1-4):295-333

Arnosti C (1998) Rapid potential rates of extracellular enzymatic hydrolysis in Arctic sediments. Limnol Oceanogr 43(2):315-324

Arnosti C, Jørgensen BB (2003) High activity and low temperature optima of extracellular enzymes in Arctic sediments: implications for carbon cycling by heterotrophic microbial communities. Mar Ecol Prog Ser 249:15-24

Arnosti C, Jørgensen BB, Sagemann J, Thamdrup B (1998) Temperature dependence of microbial degradation of organic matter in marine sediments: Polysaccharide hydrolysis, oxygen consumption, and sulfate reduction. Mar Ecol Prog Ser 165:59-70

Baldwin RJ, Smith KL Jr (2003) Temporal dynamics of particulate matter fluxes and sediment community response in Port Foster, Deception Island, Antarctica. Deep-Sea Res II 50:1707-1725

Barnes DKA, Clarke A (1995) Seasonality of feeding activity in Antarctic suspension feeders. Polar Biol 15(5):335-340

Beaulieu SE (2002) Accumulation and fate of phytodetritus on the sea floor. Oceanogr Mar Biol Annu Rev 40:171-232

Berner RA (1980) Early diagenesis: a theoretical approach. Princeton University Press, Princeton, NJ

Billett DSM, Lampitt RS, Rice AL, Mantoura RFC (1983) Seasonal sedimentation of phytoplankton to the deep-sea benthos. Nature 302:520-522

Billett DSM, Bett BJ, Rice AL, Thurston MH, Galeron J, Sibuet M, Wolff GA (2001) Long-term change in the megabenthos of the Porcupine Abyssal Plain (NE Atlantic). Prog Oceanogr 50:325-348

Boetius A, Lochte K (1996) Effect of organic enrichments on hydrolytic potentials and growth of bacteria in deep-sea sediments. Mar Ecol Prog Ser 140:239-250

Boon AR, Duineveld GCA (1998) Chlorophyll a as a marker for bioturbation and carbon flux in southern and central North Sea sediments. Mar Ecol Prog Ser 162:33-43

Boudreau BP (1997) Diagenetic models and their implementation. Springer-Verlag, Berlin

Bowman JP, McCammon SA, Gibson JAE, Robertson L, Nichols PD (2003) Prokaryotic metabolic activity and com- 
munity structure in Antarctic continental shelf sediments. Appl Environ Microbiol 69(5):2448-2462

Brockington S, Clarke A, Chapman ALG (2001) Seasonality of feeding and nutritional status during the austral winter in the Antarctic sea urchin Sterechinus neumayeri. Mar Biol 139:127-138

Brown JL, Vargo S, Connor EF, Nuckols MS (1997) Causes of vertical stratification in the density of Cameraria hamadryadella. Ecol Entomol 22:16-25

Cahoon LB, Laws RA, Thomas CJ (1994) Viable diatoms and chlorophyll $a$ in continental slope sediments off Cape Hatteras, North Carolina. Deep-Sea Res II 41(4-6):767-782

Church MJ, DeLong EF, Ducklow HW, Karner MB, Preston CM, Karl DM (2003) Abundance and distribution of planktonic Archaea and Bacteria in the waters west of the Antarctic Peninsula. Limnol Oceanogr 48(5):1893-1902

Clarke A (1988) Seasonality in the Antarctic marine environment. Comp Biochem Physiol 90B(3):461-473

Danovaro R, Dell'Anno A, Fabiano M (2001) Bioavailability of organic matter in the sediments of the Porcupine Abyssal Plain, northeastern Atlantic. Mar Ecol Prog Ser 220:25-32

Dauwe B, Middelburg JJ, Rijswijk PV, Sinke J, Herman PMJ, Heip CHR (1999) Enzymatically hydrolyzable amino acids in North Sea sediments and their possible implications for sediment nutritional values. J Mar Res 57(1):109-134

Dell'Anno A, Fabiano M, Mei ML, Danovaro R (2000) Enzymatically hydrolysed protein and carbohydrate pools in deep-sea sediments: estimates of the potentially bioavailable fraction and methodological considerations. Mar Ecol Prog Ser 196:15-23

DeMaster DJ, Smith CR, Thomas CJ, Purinton BL (2003) Radiocarbon measurements of benthic fauna as indicators of bentho-pelagic coupling and feeding strategy. EOS Trans AGU, 84(52): Ocean Sci Meet Suppl, Abstract OS52H-08

Demopoulos AWJ, Smith CR, DeMaster DJ, Fornes WL (2003) Evaluation of excess ${ }^{234} \mathrm{Th}$ activity in sediments as an indicator of food quality for deep-sea deposit feeders. J Mar Res 61:267-284

Deuser WG, Ross EH (1980) Seasonal change in the flux of organic carbon to the deep Sargasso Sea. Nature 283: 364-365

Dunbar RB, Leventer AR, Mucciarone DA (1998) Water column sediment fluxes in the Ross Sea, Antarctica: atmospheric and sea ice forcing. J Geophys Res (C Oceans) 103(C13):30741-30759

Dunbar RB, Leventer AR, Stockton WL (1989) Biogenic sedimentation in McMurdo Sound, Antarctica. Mar Geol 85: 155-179

Eisma D (1988) An introduction to the geology of continental shelves. In: Postma H, Zijlstra JJ (eds) Continental shelves, 27. Elsevier, Amsterdam, p 39-91

Fabiano M, Danovaro R (1998) Enzymatic activity, bacterial distribution, and organic matter composition in sediments of the Ross Sea (Antarctica). Appl Environ Microbiol 64(10):3838-3845

Fabiano M, Pusceddu A, Dell'Anno A, Armeni M, Vanucci S, Lampitt RS, Wolff GA, Danovaro R (2001) Fluxes of phytopigments and labile organic matter to the deep ocean in the NE Atlantic Ocean. Prog Oceanogr 50: 89-104

Fileman TW, Pond DW, Barlow RG, Mantoura RFC (1998) Vertical profiles of pigments, fatty acids and amino acids: Evidence for undegraded diatomaceous material sedimenting to the deep ocean in the Bellingshausen Sea, Antarctica. Deep-Sea Res 45:333-346

Fornes WL, DeMaster DJ, Levin LA, Blair NE (1999) Bioturba- tion and particle transport in Carolina slope sediments: a radiochemical approach. J Mar Res 57:335-355

Furlong ET, Carpenter R (1988) Pigment preservation and remineralization in oxic coastal marine sediments. Geochim Cosmochim Acta 52:87-99

Gage JD, Tyler PA (1991) Deep-sea biology: a natural history of organisms at the deep-sea floor. Cambridge University Press, New York

Gerday C, Aittaleb M, Arpigny JL, Baise E and 5 others (1999) Cold enzymes: A hot topic. In: Margesin R, Schinner F (eds) Cold adapted organisms: ecology, physiology, enzymology and molecular biology. Springer-Verlag, Berlin, p 257-275

Glud RN, Holby O, Hoffmann F, Canfield DE (1998) Benthic mineralization and exchange in Arctic sediments (Svalbard, Norway). Mar Ecol Prog Ser 173:237-251

Gooday AJ, Turley CM (1990) Responses by benthic organisms to inputs of organic material to the ocean floor: a review. Phil Trans R Soc Lond A 331:119-138

Graf G (1989) Benthic-pelagic coupling in a deep-sea benthic community. Nature 341:437-439

Graf G (1992) Benthic-pelagic coupling: a benthic view. Oceanogr Mar Biol Annu Rev 30:149-190

Graf G, Bengtsson W, Diesner U, Schulz R, Theede H (1982) Benthic response to sedimentation of a spring phytoplankton bloom: process and budget. Mar Biol 67:201-208

Graf G, Schulz R, Peinert R, Meyer-Reil LA (1983) Benthic response to sedimentation events during autumn to spring at a shallow-water station in the Western Kiel Bight I. Analysis of processes on a community level. Mar Biol 77: 235-246

Grebmeier JM, McRoy CP (1989) Pelagic-benthic coupling on the shelf of the northern Bering and Chukchi Seas. III. Benthic food supply and carbon cycling. Mar Ecol Prog Ser 53:79-91

Grebmeier JM, McRoy CP, Feder HM (1988) Pelagic-benthic coupling on the shelf of the northern Bering and Chukchi Seas. I. Food supply source and benthic biomass. Mar Ecol Prog Ser 48:57-67

Hargrave BT (1973) Coupling carbon flow through some pelagic and benthic communities. J Fish Res Board Can 30:1317-1326

Hartnett HE, Keil RG, Hedges JI, Devol AH (1998) Influence of oxygen exposure time on organic carbon preservation in continental margin sediments. Nature 391:572-574

Hartnett HE, Boehme S, Thomas CJ, DeMaster DJ, Smith CR (2005) Benthic oxygen fluxes and dentrification rates from high-resolution porewater profiles from the Western Antarctic Peninsula Continental shelf. Deep-Sea Res II (in press)

Helmke E, Weyland H (1991) Effect of temperature on extracellular enzymes occurring in permanently cold marine environments. Kiel Meeresforsch Sonderh 8:198-204

Honjo S (1990) Particle fluxes and modern sedimentation in the Polar Oceans. Polar Oceanogr Part B 13:688-739

Huston AL, Krieger-Brockett BB, Deming JW (2000) Remarkably low temperature optima for extracellular enzyme activity from Arctic bacteria and sea ice. Environ Microbiol 2(4):383-388

Josefson AB, Forbes TL, Rosenberg R (2002) Fate of phytodetritus in marine sediments: functional importance of macrofaunal community. Mar Ecol Prog Ser 230:71-85

Jumars PA, Deming JW, Hill PS, Karp-Boss L, Yager PL, Dade WB (1993) Physical constraints on marine osmotrophy in an optimal foraging context. Mar Microb Food Webs 7: 121-159

Karl DM (1993) Total microbial biomass estimation derived 
from the measurement of particulate adenosine-5'triphosphate. In: Kemp PF, Sherr BF, Cole JJ (eds) Handbook of methods in aquatic microbial ecology. Lewis Publishers, Boca Raton, FL, p 359-368

Karl DM, Craven DB (1980) Effects of alkaline phosphatase activity on nucleotide measurements in aquatic microbial communities. Appl Environ Microbiol 40(3):549-561

Karl DM, Christian JR, Dore JE, Letelier RM (1996) Microbiological oceanography in the region west of the Antarctic Peninsula: microbial dynamics, nitrogen cycle and carbon flux. In: Ross R, Hofmann E, Quetin L (eds) Foundations for ecological research west of the Antarctic Peninsula. Antarctic Research Series, Vol 70. American Geophysical Union, Washington, DC, p 303-332

Lampitt RS (1985) Evidence for the seasonal deposition of detritus to the deep-sea floor and its subsequent resuspension. Deep-Sea Res 32:885-897

Levin LA, Gooday AJ (2003) The deep Atlantic ocean floor. In: Tyler PA (ed) Ecosystems of the deep oceans, 28. Elsevier Science, Amsterdam, p 111-178

Mantoura RFC, Llewellyn CA (1983) The rapid determination of algal chlorophyll and carotenoid pigments and their breakdown products in natural waters by reverse-phase high-performance liquid chromatography. Anal Chim Acta 151:297-314

Mantoura RFC, Jeffrey SW, Llewellyn CA, Claustre $H_{\text {, }}$ Morales CE (1997) Comparison between spectrophotometric, fluorometric and HPLC methods for chlorophyll analysis. In: Jeffrey SW, Mantoura RFC, Wright SW (eds) Phytoplankton pigments in oceanography. UNESCO Publishing, Paris, p 361-380

Mayer LM, Schick LL, Sawyer T, Plante CJ, Jumars PA, Self RL (1995) Bioavailable amino acids in sediments: a biomimetic, kinetics-based approach. Limnol Oceanogr 40(3):511-520

McClintic MA (2002). The delivery and fate of particles settling on the seabed adjacent to the western Antarctic Peninsula: evidence from excess ${ }^{234} \mathrm{Th}$ measurements. MS thesis, North Carolina State University, Raleigh, NC

Meyer-Reil LA (1983) Benthic response to sedimentation events during autumn to spring at a shallow water station in the Western Kiel Bight II. Analysis of benthic bacterial populations. Mar Biol 77:247-256

Meyer-Reil LA, Koster M (1992) Microbial life in pelagic sediments: the impact of environmental parameters on enzymatic degradation of organic material. Mar Ecol Prog Ser 81:65-72

Nedwell DB (1984) The input and mineralization of organic carbon in anaerobic aquatic sediments. Adv Microb Ecol 7:93-131

Nedwell DB (1999) Effect of low temperature on microbial growth: Lowered affinity for substrates limits growth at low temperature. FEMS Microbiol Ecol 30:101-111

Nedwell DB, Rutter M (1994) Influence of temperature on growth rate and competition between two psychrotolerant Antarctic bacteria: low temperature diminishes affinity for substrate uptake. Appl Environ Microbiol 60(6): 1984-1992

Nedwell DB, Walker TR, Ellis-Evans JC, Clarke A (1993) Measurements of seasonal rates and annual budgets of organic carbon fluxes in an Antarctic coastal environment at Signy Island, South Orkney Islands, suggest a broad balance between production and decomposition. Appl Environ Microbiol 59(12):3989-3995

Pfannküche O, Boetius A, Lochte K, Lundgreen U, Thiel H (1999) Responses of deep-sea benthos to sedimentation patterns in the North-East Atlantic in 1992. Deep-Sea Res
46:573-596

Piepenburg D, Ambrose WG Jr, Brandt A, Renaud PE, Ahrens MJ, Jensen P (1997) Benthic community patterns reflect water column processes in the Northeast Water polynya (Greenland). J Mar Syst 10:467-482

Pomeroy LR, Deibel D (1986) Temperature regulation of bacterial activity during the spring bloom in Newfoundland coastal waters. Science 233:359-361

Pomeroy LR, Wiebe WJ (2001) Temperature and substrates as interactive limiting factors for marine heterotrophic bacteria. Aquat Microb Ecol 23:187-204

Pomeroy LR, Wiebe WJ, Deibel D, Thompson RJ, Rowe GT, Pakulski JD (1991) Bacterial responses to temperature and substrate concentration during the Newfoundland spring bloom. Mar Ecol Prog Ser 75:143-159

Price PB, Sowers T (2004) Temperature dependence of metabolic rates for microbial growth, maintenance, and survival. Proc Natl Acad Sci 101(13):4631-4636

Pusceddu A, Dell'Anno A, Danovaro R, Manini E, Sara G, Fabiano M (2003) Enzymatically hydrolyzable protein and carbohydrate sedimentary pools as indicators of the trophic state of detritus sink systems: a case study in a Mediterranean coastal lagoon. Estuaries 26(3):641-650

Reay DS, Nedwell DB, Priddle J, Ellis-Evans JC (1999) Temperature dependence of inorganic nitrogen uptake: reduced affinity for nitrate at suboptimal temperatures in both algae and bacteria. Appl Environ Microbiol 65(6): $2577-2584$

Schlesinger WH (1997) Biogeochemistry: an analysis of global change. Academic Press, San Diego, CA

Smith CR, Demopoulos AWJ (2003) The Deep Pacific Ocean Floor. In: Tyler PA (ed) Ecosystems of the deep oceans, 28. Elsevier Science, Amsterdam, p 179-218

Smith CR, Pope RH, DeMaster DJ, Magaard L (1993) Agedependent mixing of deep-sea sediments. Geochim Cosmochim Acta 57:1473-1488

Smith CR, Walsh ID, Jahnke RA (1994) Adding biology to one-dimensional models of sediment-carbon degradation: The multi-B approach. In: Rowe GT, Pariente V (eds) Deep-sea food chains and the global carbon cycle. Kluwer Academic Publishers, Dordrecht, p 395-400

Smith CR, Hoover DJ, Doan SE, Pope RH, DeMaster KJ, Dobbs FC, Altabet MA (1996) Phytodetritus at the abyssal sea floor across 10 of latitude in the central equatorial Pacific. Deep-Sea Res Part II 43:1309-1338

Smith CR, Berelson W, DeMaster DJ, Dobbs FC, Hammond D, Hoover DJ, Pope RH, Stephens M (1997) Latitudinal variations in benthic processes in the abyssal equatorial Pacific: control by biogenic particle flux. Deep-Sea Res Part II 44(9-10):2295-2317

Smith CR, Mincks SL, DeMaster DJ (2005) The Foodbank Project: introduction and sinking fluxes of organic carbon, chlorophyll $a$, and phytodetritus on the Western Antarctic Peninsula shelf. Deep-Sea Res II (in press)

Smith KL, Kaufmann RS, Baldwin RJ, Carlucci AF (2001) Pelagic-benthic coupling in the abyssal eastern North Pacific: an 8-year time-series study of food supply and demand. Limnol Oceanogr 46(3):453-556

Smith RC, Dierssen HM, Vernet M (1996) Phytoplankton biomass and productivity in the Western Antarctica Peninsula region. In: Ross R, Hoffman E, Quetin L (eds) Foundations for ecological research west of the Antarctic Peninsula. Antarctic Research Series, Vol 70. American Geophysical Union, Washington, DC, p 333-356

Smith RC, Fraser WR, Stammerjohn SE (2003) Climate variability and ecological response of the marine ecosystem in the Western Antarctic Peninsula (WAP) region. In: Green- 
land D, Goodin DG, Smith RC (eds) Climate variability and ecosystem response at long-term ecological research sites. Oxford University Press, Oxford, p 158-173

Sokal RR, Rohlf FJ (1995) Biometry: the principles and practice of statistics in biological research. WH Freeman, New York

Stephens MP, Kadko DC, Smith CR, Latasa M (1997) Chlorophyll-a and phaeopigments as tracers of labile organic carbon at the central equatorial Pacific sea floor. Geochim Cosmochim Acta 61(21):4605-4619

Suhr SB, Pond DW, Gooday AJ, Smith CR (2003) Selective feeding by benthic foraminifera on phytodetritus on the western Antarctic Peninsula shelf: evidence from fatty acid biomarker analysis. Mar Ecol Prog Ser 262:153-162

Sun MY, Aller RC, Lee C (1991) Early diagenesis of chlorophyll-a in Long Island Sound sediments: a measure of carbon flux and particle reworking. J Mar Res 49:379-401

Sun MY, Aller RC, Lee C (1994) Spatial and temporal distributions of sedimentary chloropigments as indicators of benthic processes in Long Island Sound. J Mar Res 52: 149-176

Sun MY, Lee C, Aller RC (1993) Laboratory studies of oxic and

Editorial responsibility: Otto Kinne (Editor-in-Chief),

Oldendorf/Luhe, Germany anoxic degradation of chlorophyll-a in Long Island Sound sediments. Geochim Cosmochim Acta 57:147-157

Tyler PA (1988) Seasonality in the deep sea. Oceanogr Mar Biol Annu Rev 26:227-258

Wefer G, Fischer G, Fuetterer D, Gersonde R (1988) Seasonal particle flux in the Bransfield Straight, Antarctica. DeepSea Res 35:891-898

Wiebe WJ, Sheldon WM Jr, Pomeroy LR (1992) Bacterial growth in the cold: evidence for an enhanced substrate requirement. Appl Environ Microbiol 58(1):359-364

Wiebe WJ, Sheldon WM Jr, Pomeroy LR (1993) Evidence for an enhanced substrate requirement by marine mesophilic bacterial isolates at minimal growth temperatures. Microb Ecol 25:151-159

Yager PL, Deming JW (1999) Pelagic microbial activity in an arctic polynya: testing for temperature and substrate interactions using a kinetic approach. Limnol Oceanogr 44(8): 1882-1893

Yager PL, Wallace DWR, Johnson KM, Smith WO Jr, Minnett PJ, Deming JW (1995) The Northeast Water Polynya as an atmospheric $\mathrm{CO}_{2}$ sink: a seasonal rectification hypothesis. J Geophys Res 100(C3):4389-4398

Submitted: October 27, 2004; Accepted: April 12, 2005

Proofs received from author(s): August 9, 2005 